Atmos. Chem. Phys., 19, 15321-15337, 2019

https://doi.org/10.5194/acp-19-15321-2019

(C) Author(s) 2019. This work is distributed under

the Creative Commons Attribution 4.0 License.

\title{
Impact of halogen chemistry on summertime air quality in coastal and continental Europe: application of the CMAQ model and implications for regulation
}

\author{
Qinyi $\mathrm{Li}^{1}$, Rafael Borge ${ }^{2}$, Golam Sarwar ${ }^{3}$, David de la $\mathrm{Paz}^{2}$, Brett Gantt ${ }^{4}$, Jessica Domingo ${ }^{2}$, Carlos A. Cuevas ${ }^{1}$, and \\ Alfonso Saiz-Lopez ${ }^{1}$ \\ ${ }^{1}$ Department of Atmospheric Chemistry and Climate, Institute of Physical Chemistry Rocasolano, \\ CSIC, Madrid 28006, Spain \\ ${ }^{2}$ Environmental Modelling Laboratory, Department of Chemical \& Environmental Engineering, \\ Universidad Politécnica de Madrid (UPM), Madrid, Spain \\ ${ }^{3}$ National Exposure Research Laboratory, Environmental Protection Agency, Research Triangle Park, NC 27711, USA \\ ${ }^{4}$ Office of Air Quality Planning and Standards, Environmental Protection Agency, Research Triangle Park, NC 27711, USA
}

Correspondence: Alfonso Saiz-Lopez (a.saiz@csic.es)

Received: 19 February 2019 - Discussion started: 23 April 2019

Revised: 21 October 2019 - Accepted: 28 October 2019 - Published: 16 December 2019

\begin{abstract}
Halogen $(\mathrm{Cl}, \mathrm{Br}$, and $\mathrm{I})$ chemistry has been reported to influence the formation of secondary air pollutants. Previous studies mostly focused on the impact of chlorine species on air quality over large spatial scales. Very little attention has been paid to the effect of the combined halogen chemistry on air quality over Europe and its implications for control policy. In the present study, we apply a widely used regional model, the Community Multiscale Air Quality Modeling System (CMAQ), incorporated with the latest halogen sources and chemistry, to simulate the abundance of halogen species over Europe and to examine the role of halogens in the formation of secondary air pollution. The results suggest that the CMAQ model is able to reproduce the level of $\mathrm{O}_{3}, \mathrm{NO}_{2}$, and halogen species over Europe. Chlorine chemistry slightly increases the levels of $\mathrm{OH}, \mathrm{HO}_{2}, \mathrm{NO}_{3}, \mathrm{O}_{3}$, and $\mathrm{NO}_{2}$ and substantially enhances the level of the $\mathrm{Cl}$ radical. Combined halogen chemistry induces complex effects on $\mathrm{OH}$ (ranging from -0.023 to $0.030 \mathrm{pptv}$ ) and $\mathrm{HO}_{2}$ (in the range of -3.7 to $0.73 \mathrm{pptv}$ ), significantly reduces the concentrations of $\mathrm{NO}_{3}$ (as much as 20 pptv) and $\mathrm{O}_{3}$ (as much as $10 \mathrm{ppbv}$ ), and decreases $\mathrm{NO}_{2}$ in highly polluted regions (as much as $1.7 \mathrm{ppbv}$ ); it increases $\mathrm{NO}_{2}$ (up to $0.20 \mathrm{ppbv}$ ) in other areas. The maximum effects of halogen chemistry occur over oceanic and coastal regions, but some noticeable impacts also occur over continental Europe. Halogen chemistry
\end{abstract}

affects the number of days exceeding the European Union target threshold for the protection of human beings and vegetation from ambient $\mathrm{O}_{3}$. In light of the significant impact of halogen chemistry on air quality, we recommend that halogen chemistry be considered for inclusion in air quality policy assessments, particularly in coastal cities.

\section{Introduction}

Halogen $(\mathrm{Cl}, \mathrm{Br}$, and $\mathrm{I})$ species and related processes have been known to deplete stratospheric ozone $\left(\mathrm{O}_{3}\right)$ for several decades (Molina and Rowland, 1974; Farman et al., 1985). In the troposphere, the chemistry of halogens has been described in detail in recent reviews and references therein (Saiz-Lopez and von Glasow, 2012; Simpson et al., 2015), so it is just briefly outlined here. Halogen species affect the concentration of air pollutants by, e.g., directly destroying $\mathrm{O}_{3}$ (Reaction $\mathrm{R} 1$ ), indirectly decreasing $\mathrm{O}_{3}$ production by reducing $\mathrm{NO}_{2}$ (Reactions $\mathrm{R} 2$ and $\mathrm{R} 3$ ), and influencing the $\mathrm{NO} / \mathrm{NO}_{2}$ ratio (Reactions $\mathrm{R} 2$ and $\mathrm{R} 4$ ) and the $\mathrm{HO}_{2} / \mathrm{OH}$ ratio (Reactions R5 and R6). The budgets of $\mathrm{NO}_{x}\left(\mathrm{NO}+\mathrm{NO}_{2}\right)$ and $\mathrm{HO}_{x}\left(\mathrm{OH}+\mathrm{HO}_{2}\right)$ also affect the formation of $\mathrm{O}_{3}$ (e.g., Sillman, 1999; Li et al., 2018).

$\mathrm{X}(\mathrm{Cl}, \mathrm{Br}, \mathrm{I})+\mathrm{O}_{3} \rightarrow \mathrm{XO}+\mathrm{O}_{2}$ 
$\mathrm{XO}+\mathrm{NO}_{2} \rightarrow \mathrm{XONO}_{2}$

$\mathrm{XONO}_{2}+\mathrm{H}_{2} \mathrm{O}(l) \rightarrow \mathrm{HOX}+\mathrm{HNO}_{3}(l)$

$\mathrm{XO}+\mathrm{NO} \rightarrow \mathrm{X}+\mathrm{NO}_{2}$

$\mathrm{XO}+\mathrm{HO}_{2} \rightarrow \mathrm{HOX}+\mathrm{O}_{2}$

$\mathrm{HOX}+h v \rightarrow \mathrm{OH}+\mathrm{X}$

The chlorine radical $(\mathrm{Cl})$ initiates the oxidation of hydrocarbons (Reaction R7), including methane $\left(\mathrm{CH}_{4}\right)$ and nonmethane volatile organic compounds (NMVOCs), in a similar way to the $\mathrm{OH}$ radical, reducing the lifetime of $\mathrm{CH}_{4}$ and NMVOCs and leading to the formation of $\mathrm{O}_{3}$ in the presence of $\mathrm{NO}_{x}$ (Thornton et al., 2010).

$\mathrm{RH}+\mathrm{Cl} \rightarrow \mathrm{HCl}+\mathrm{RO}_{2}$

The combined effect of halogen chemistry on air quality is therefore complicated and depends heavily on local conditions, e.g., atmospheric compositions and oxidative capacity (Sherwen et al., 2017; Muñiz-Unamunzaga et al., 2018). Evaluation of the complex role of halogen chemistry in air quality requires the employment of advanced, high-resolution chemical transport models.

A number of modeling studies have been conducted to investigate the impact of individual halogen species on air quality. The chemistry of chlorine, mainly that of nitryl chloride $\left(\mathrm{ClNO}_{2}\right)$, has been reported to increase the oxidation capacity and the formation of $\mathrm{O}_{3}$ in recent studies (Sarwar et al., 2012, 2014; Li et al., 2016; Sherwen et al., 2017; Sommariva et al., 2018). Bromine (Fernandez et al., 2014) and iodine (Saiz-Lopez et al., 2014) chemistry are reported to decrease the concentration of $\mathrm{O}_{3}$ over oceanic and terrestrial regions.

Only a few regional modeling studies have explored the combined influence of halogen chemistry on air quality. The first modeling study with combined halogen $(\mathrm{Cl}, \mathrm{Br}$, and I) chemistry was conducted by Sarwar et al. (2015), who used a hemispheric version of the Community Multiscale Air Quality (CMAQ) model (Byun and Ching, 1999; Byun and Schere, 2006; Mathur et al., 2017) and reported a decrease in surface $\mathrm{O}_{3}$ by $\sim 15 \%$ to $\sim 48 \%$ over the Northern Hemisphere by $\mathrm{Br}$ and I. Gantt et al. (2017) then utilized the CMAQ model to explore the role of halogen chemistry at a regional scale over the continental United States (US). While these studies focused on the Northern Hemisphere and the continental US, Muñiz-Unamunzaga et al. (2018) applied the full halogen chemistry version of CMAQ with a resolution of $4 \mathrm{~km}$ and reported an up to $5 \mathrm{ppbv}$ decrease in $\mathrm{O}_{3}$ in the city of Los Angeles, California, US. Sherwen et al. (2017) used a global model, GEOS-Chem, in a regional configuration (with a grid size of $0.25^{\circ} \times 0.315^{\circ}, \sim 25 \mathrm{~km} \times \sim 25 \mathrm{~km}$ ) and predicted a large decrease in $\mathrm{O}_{3}$, on average $13.5 \mathrm{pptv}$ (25\%) and as much as 28.9 pptv (45\%), in Europe. Sarwar et al. (2019) further updated the halogen chemistry in the CMAQ model and reported a reduction of 3 to $12 \mathrm{ppbv}$ in annual average $\mathrm{O}_{3}$ over seawater, 3 to 6 ppbv over coastal areas, and 3 ppbv over inland areas by $\mathrm{Br}$ and I. These previous regional studies using various models (or versions of models) in different areas reported a large range of the halogen impact on $\mathrm{O}_{3}$, highlighting the uncertainty in this research field.

The regulation of air quality and the control of air pollutants emission in Europe started in the early 1970s and over 40 years of effort has successfully improved air quality throughout Europe (EEA, 2018a). Nonetheless, poor air quality persists in major cities like Madrid, Paris, and London (EEA, 2018a); this shows the need for continued air quality management and effective policy. Because the influence of halogens on air quality is uncertain and potentially has an impact on air quality management decisions, we have conducted regional simulations using the latest version of the CMAQ model implemented with comprehensive halogen sources and chemistry (Sarwar et al., 2019) to examine the overall effect of halogen species on air pollution over Europe. Considering that the grid size has a noticeable impact on air quality model predictions (Sommariva et al., 2018), we used a CMAQ model domain with $12 \mathrm{~km}$ horizontal resolution (higher than the previous studies on the halogen impact covering Europe) to simulate the levels of halogen species over Europe, examine the effect on the oxidation capacity and the concentration of air pollutants, and explore the potential implications for air quality policy related to $\mathrm{NO}_{2}$ and $\mathrm{O}_{3}$.

\section{Method and materials}

\subsection{Data}

The meteorological inputs for the CMAQ model were obtained from the Weather Research and Forecasting model (WRF 3.7.1) (Skamarock and Klemp, 2008; Borge et al., 2008a) as an offline input. The WRF model was initialized from global reanalyses from the National Centers for Environmental Prediction (NCEP) Global Forecast System (GFS) with a spatial resolution of $1^{\circ} \times 1^{\circ}$ and a temporal resolution of $6 \mathrm{~h}$ (available online at http://rda.ucar.edu/datasets/ ds083.2/, last access: 22 November 2019), which was updated daily from NCEP global analyses with $0.5^{\circ}$ resolution (available online at http://www.nco.ncep.noaa.gov/pmb/ products/sst/, last access: 22 November 2019). NCEP's ADP global upper-air (NCAR archive ds351.0) and global surface observations (NCAR archive ds461.0) were used to drive the simulation with a Newtonian relaxation technique in the WRF model.

Anthropogenic emissions for the year 2016 were taken from the $0.1^{\circ} \times 0.1^{\circ}$ gridded EMEP inventory (EMEP/CEIP, 2014). It should be noted that no anthropogenic chlorine sources are included in our emission inventory. The temporal profiles and vertical distribution needed to resolve the 
emissions were those used in the EuroDelta experiment (van Loon et al., 2007). Biogenic emissions were estimated using the Model of Emissions of Gases and Aerosols from Nature (MEGANv2.10) (Guenther et al., 2012). All emissions were gridded to our model domain, temporally allocated, and chemically speciated using the Sparse Matrix Operator Kernel Emissions (SMOKE) model version 3.6.5 (UNC, 2015; Borge et al., 2008b).

In addition, we used measurement data on $\mathrm{NO}_{2}$ and $\mathrm{O}_{3}$ from over 400 background stations (traffic and industrial stations are not included) across Europe from the database AirBase (public air quality database system of the EEA, 2018a) to compare the results of our simulation with observations (Fig. 1). Among these stations, 315 are located in inland areas (208 for $\mathrm{NO}_{2}$ and 266 for $\mathrm{O}_{3}$ ), and 125 are located in coastal areas ( 83 for $\mathrm{NO}_{2}$ and 93 for $\mathrm{O}_{3}$ ).

\subsection{Modeling system}

The CMAQ model is widely used and includes comprehensive representations of many essential atmospheric processes. The skill of the model in reproducing observed air quality has been demonstrated in many previous studies (Foley et al., 2010; Appel et al., 2013, 2017; Mathur et al., 2017), including applications over Europe (Borge et al., 2008a; Appel et al., 2012; Solazzo et al., 2017). CMAQ version 5.2 (https://www.epa.gov/cmaq, last access: 22 November 2019; https://doi.org/10.5281/zenodo.1167892, US EPA ORD, 2017) containing the Carbon Bond chemical mechanism (Appel et al., 2017) with halogen chemistry was used in this study. We updated the chlorine chemistry of Sarwar et al. (2012) and implemented it in CMAQ version 5.2 (Table $\mathrm{S} 1$ in the Supplement). The heterogeneous hydrolysis of dinitrogen pentoxide $\left(\mathrm{N}_{2} \mathrm{O}_{5}\right)$ can produce $\mathrm{ClNO}_{2}$ and nitric acid $\left(\mathrm{HNO}_{3}\right)$ in the presence of particulate chloride. In the absence of particulate chloride, the heterogeneous hydrolysis of $\mathrm{N}_{2} \mathrm{O}_{5}$ produces only $\mathrm{HNO}_{3}$. Sarwar et al. (2015) implemented the initial bromine and iodine chemistry in CMAQ, which has recently been updated by Sarwar et al. (2019). The updates include revising the gas-phase bromine and iodine reactions, incorporating several heterogeneous reactions of bromine and iodine species, incorporating several aqueousphase bromine reactions, and revising the iodine and bromine emissions. We combine the updated chlorine, bromine, and iodine chemistry with the Carbon Bond chemical mechanism and use it in this study.

\subsection{Simulation setup}

A detailed description of physics and other model options (Table S2) can be found in de la Paz et al. (2016). The CMAQ model is applied over a domain covering the entirety of Europe (Fig. 1) with $12 \mathrm{~km}$ horizontal resolution. The vertical extent of the model extended from the surface to $100 \mathrm{mbar}$ and contained 35 layers with an average surface layer thick- ness of approximately $20 \mathrm{~m}$. The CMAQ chemical transport model is configured to use the piecewise parabolic method to describe advection processes, the Asymmetric Convective Model (version 2) to describe vertical diffusion processes, and the multiscale method to describe horizontal diffusion processes. Gas-phase chemistry, aqueous chemistry, aerosol processes, and dry and wet deposition were also included. The Rosenbrock solver was used for gas-phase chemistry.

The study was completed for the month of July 2016 with a spin-up period of $30 \mathrm{~d}$. We performed three simulations to isolate the effect of halogen chemistry on air quality (in brackets is the name of the scenario used hereafter):

1. base model without halogen chemistry (BASE),

2. BASE with chlorine chemistry (CL), and

3. CL with Br and I chemistry (HAL).

The BASE model simulation includes the Carbon Bond 2015 chemical mechanism but does not contain any halogen chemistry, and only $\mathrm{HNO}_{3}$ is produced from the heterogeneous hydrolysis of $\mathrm{N}_{2} \mathrm{O}_{5}$. The $\mathrm{CL}$ simulation contains the Carbon Bond chemical mechanism with chlorine chemistry and considers $\mathrm{ClNO}_{2}$ and $\mathrm{HNO}_{3}$ production from the heterogeneous uptake of $\mathrm{N}_{2} \mathrm{O}_{5}$ on the aerosol surface. The HAL simulation contains the Carbon Bond chemical mechanism with full halogen chemistry and produces $\mathrm{ClNO}_{2}$ and $\mathrm{HNO}_{3}$ from the heterogeneous uptake of $\mathrm{N}_{2} \mathrm{O}_{5}$ on the aerosol surface.

Boundary conditions for the model were derived from the hemispheric CMAQ simulations (Mathur et al., 2017). Three different annual simulations were conducted using the hemispheric CMAQ model for 2016: the first simulation used the Carbon Bond chemical mechanism without any halogen chemistry, the second simulation used the Carbon Bond chemical mechanism and the chlorine chemistry, and the third simulation used the Carbon Bond chemical mechanism and the full halogen chemistry. Results from the corresponding hemispheric CMAQ simulation were used to generate boundary conditions for the BASE, CL, and HAL simulations. Therefore, the difference between CL and BASE simulations represents the impact of the chlorine chemistry on air quality, and the difference between HAL and BASE simulations represents the effect of halogen chemistry on air quality.

\section{Results and discussion}

\subsection{Evaluation of model performance}

The performance of the CMAQ model in simulating air quality over Europe is evaluated using observation data collected from $>400$ measurement stations. We separate the stations into coastal (within $24 \mathrm{~km}$ of the coast) and continental stations (Fig. 1). Table 1 presents the statistics of the model performance for $\mathrm{O}_{3}$ and $\mathrm{NO}_{2}$ for BASE and HAL simulations. 


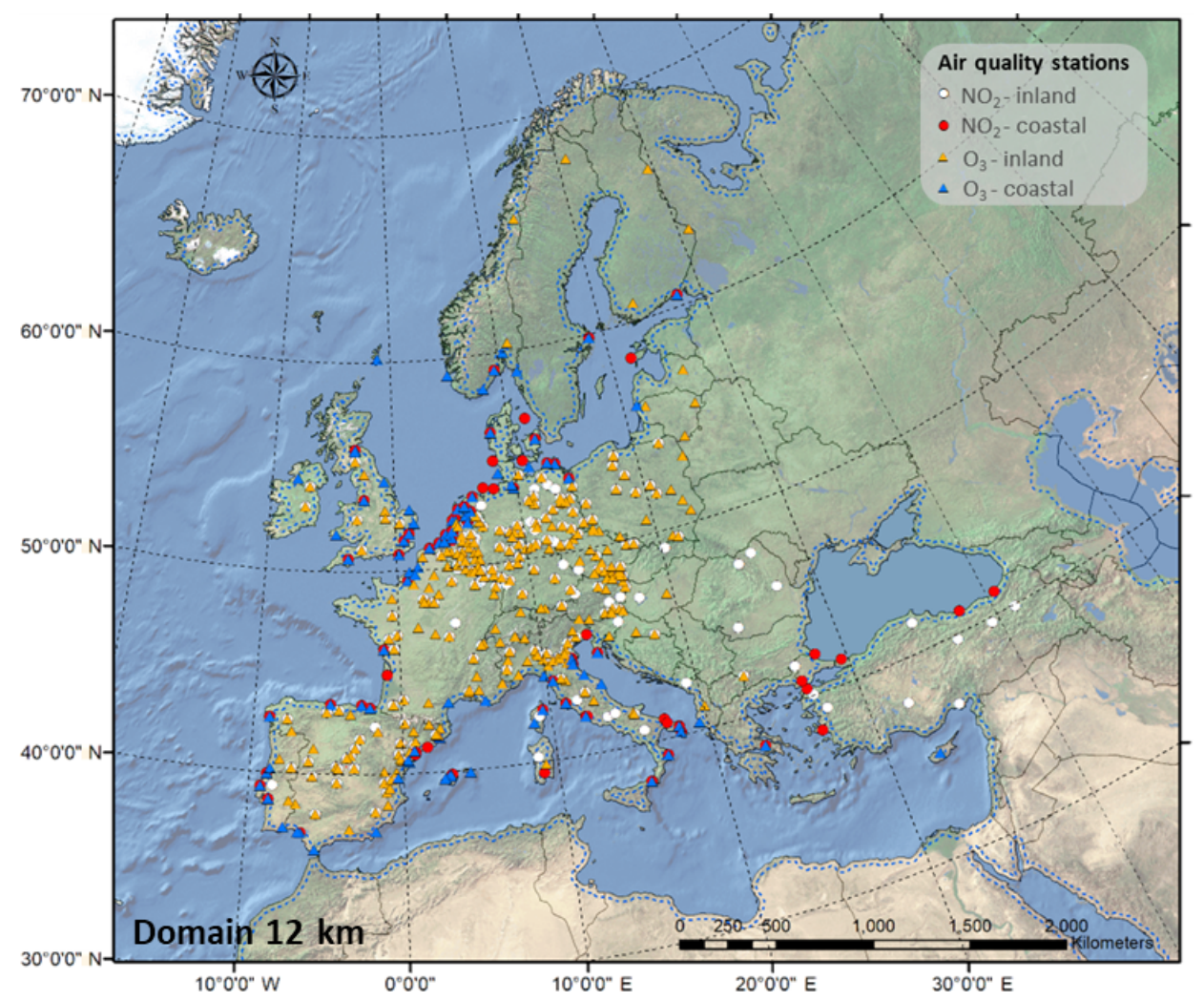

Figure 1. Geographic representation of the modeling domain and the air quality stations used for model evaluation.

The BASE and HAL simulations generally reproduce the concentration levels and the temporal variations of $\mathrm{O}_{3}$ and $\mathrm{NO}_{2}$ both at coastal and continental stations. The correlation coefficients between simulations and observations (Fig. S1 in the Supplement) show that CMAQ satisfactorily reproduces the variation of $\mathrm{O}_{3}$ and $\mathrm{NO}_{2}$ over most of Europe, especially the coastal regions $\left(>0.6\right.$ for $\mathrm{O}_{3}$ and $>0.4$ for $\mathrm{NO}_{2}$ ). The BASE simulation underpredicts $\mathrm{O}_{3}$ compared to observations at both coastal and continental stations (Table 1), possibly due to the uncertainty of the NMVOC emission inventory (Sherwen et al., 2017) and the underestimated $\mathrm{NO}_{x}$ (Table 1). The HAL simulation slightly improves the correlation coefficient of $\mathrm{O}_{3}$ but decreases the average level of $\mathrm{O}_{3}$ compared to the BASE case. Diurnal variation plots (Fig. S2) suggest that both BASE and HAL simulations can reproduce the temporal patterns of $\mathrm{O}_{3}$.

The BASE simulation underpredicts $\mathrm{NO}_{2}$ compared to observations at both coastal and continental stations (Table 1). Such an underestimation of $\mathrm{NO}_{2}$ can occur for many reasons, including (1) positive artifacts of $\mathrm{NO}_{2}$ monitors (Jung et al., 2017), (2) underestimation of $\mathrm{NO}_{x}$ in the emission inventory, and (3) rapid transformation of $\mathrm{NO}_{2}$ into $\mathrm{HNO}_{3}$ in the model compared to the real atmosphere. Model performance is reasonable as the $\mathrm{NO}_{2}$ underestimation is relatively small. The HAL case predicted very similar $\mathrm{NO}_{2}$ concentrations (Table 1).
Overall, the evaluation of CMAQ results over Europe demonstrates that the model is capable of reproducing the levels of atmospheric chemical species and can be used to investigate the impact of halogen chemistry on air quality over Europe. It also suggests that the incorporation of halogen chemistry changes the model performance for $\mathrm{O}_{3}$ concentrations by a small margin without a noticeable impact on the model performance for $\mathrm{NO}_{2}$.

\subsection{Simulated halogen species}

Average surface concentrations of the inorganic halogen species predicted in the HAL simulation over the ocean are summarized in Table $2 . \mathrm{HCl}$ is the dominant chlorine species, with an average level of $247.9 \mathrm{pptv}$ representing over $96 \%$ of the total inorganic chlorine $\left(\mathrm{Cl}_{y}\right)$, while the average $\mathrm{ClNO}_{2}$ and $\mathrm{HOCl}$ is $4.9 \mathrm{pptv}(1.9 \%)$ and $3.8 \mathrm{pptv}(1.5 \%)$, respectively, with the remaining species contributing less than $1 \%$. The $\mathrm{Br}_{y}$ species are relatively evenly partitioned, with $\mathrm{HOBr}$ (1.06 pptv, 27.0\%), $\mathrm{BrCl}(0.71 \mathrm{pptv}, 18.2 \%)$, $\mathrm{BrNO}_{3}(0.67 \mathrm{pptv}, 16.9 \%), \mathrm{HBr}(0.66 \mathrm{pptv}, 16.8 \%)$, and $\mathrm{Br}_{2}$ (0.33 pptv, $8.4 \%$ ) being the abundant species, while the remaining species contribute $<5 \%$. HOI ( $5.1 \mathrm{pptv}, 52.0 \%)$, $\mathrm{INO}_{3}(2.8 \mathrm{pptv}, 28.7 \%)$, and IO (1.0 pptv, $10.3 \%$ ) contribute over $90 \%$ of $\mathrm{I}_{y}$ over the ocean, while the remaining species contribute $\sim 10 \%$. The predicted average concentrations of 
Table 1. Statistical summary of model performance.

\begin{tabular}{lrr|rr|rr|r|r}
\hline \multirow{2}{*}{ Statistics } & \multicolumn{3}{c|}{$\mathrm{O}_{3}\left(\mu \mathrm{g} \mathrm{m}^{-3}\right)$} & \multicolumn{3}{c}{$\mathrm{NO}_{2}\left(\mu \mathrm{g} \mathrm{m}^{-3}\right)$} \\
\cline { 2 - 9 } & \multicolumn{2}{c}{ Coastal } & \multicolumn{2}{|c|}{ Inland } & \multicolumn{2}{c}{ Coastal } & \multicolumn{2}{c}{ Inland } \\
\cline { 2 - 9 } & Base & HAL & Base & HAL & Base & HAL & Base & HAL \\
\hline MB & -0.9 & -6.8 & -2.3 & -6.6 & -3.7 & -3.7 & -3.1 & -3.1 \\
ME & 16.9 & 17.5 & 19.7 & 20.2 & 5.8 & 5.8 & 5.7 & 5.6 \\
RMSE & 22.6 & 23.1 & 25.8 & 26.4 & 7.7 & 7.7 & 7.2 & 7.2 \\
$r$ & 0.65 & 0.67 & 0.60 & 0.61 & 0.44 & 0.44 & 0.42 & 0.42 \\
IOA & 0.64 & 0.62 & 0.62 & 0.61 & 0.31 & 0.31 & 0.18 & 0.19 \\
\hline
\end{tabular}

MB: mean bias, RMSE: root mean square error, $r$ : correlation coefficient, IOA: index of agreement.

the critical halogen radicals, $\mathrm{Cl}, \mathrm{BrO}$, and $\mathrm{IO}$, are $2.0 \times 10^{-4}$, 0.03 , and $0.4 \mathrm{pptv}$, respectively, over the ocean in Europe.

The spatial distributions of key halogen species are shown in Fig. 2. The HAL simulation with full halogen chemistry simulates generally higher $\mathrm{ClNO}_{2}$ levels (with the highest monthly average value of $113.0 \mathrm{pptv}$ ) along the coast of the Mediterranean Sea and the North Sea with some influence into continental Europe, especially in Germany. The simulated $\mathrm{HCl}$ shows a similar pattern to that of $\mathrm{ClNO}_{2}$ but with a much higher concentration ( $>10$ times higher). The predicted $\mathrm{BrO}$ levels over Europe are low (average value $0.17 \mathrm{pptv}$ ), with the largest predicted value occurring within the Arctic Circle, while GEOS-Chem predicted $>1.0 \mathrm{pptv}$ of $\mathrm{BrO}$ in the Mediterranean Sea (Sherwen et al., 2017). The predicted IO peaks over the Mediterranean region with a maximum value of $6.9 \mathrm{pptv}$.

Direct measurements of halogen species are very scarce and not available for the period covered in the present study (July 2016). Since a direct comparison is not possible, here we present a comparison of the simulated concentrations with observations from previous studies (Table 3 ) to provide an approximate assessment of the representation of halogen species in the HAL simulation of the CMAQ model over Europe.

Numerous $\mathrm{ClNO}_{2}$ measurements have been reported around the globe, which show that $\mathrm{ClNO}_{2}$ is ubiquitous in the boundary layer, with maximum values ranging from hundreds to thousands of parts per trillion by volume in polluted coastal (Osthoff et al., 2008; Wang et al., 2016) and continental regions (Tham et al., 2016; Thornton et al., 2010). A few campaigns have been conducted in Europe. Phillips et al. (2012) reported a maximum value of $800 \mathrm{pptv}$ for $\mathrm{ClNO}_{2}$ in Hessen, Germany, where CMAQ predicts a concentration of 273 pptv. Bannan et al. (2015) observed a peak value of 724 pptv in London where CMAQ predicts a concentration of 802 pptv. Simulations with the GEOS-Chem model (Sherwen et al., 2017) reported maximum values of 110 and 140 pptv in Hessen and London, respectively. Several field campaigns have been conducted in Weybourne in the past few years to measure $\mathrm{ClNO}_{2}$. Sherwen et al. (2017) reported a peak concentration of 946 pptv. Bannan et al. (2017) reported a peak value of $65 \mathrm{pptv}$, and Sommariva et al. (2018) reported a peak value of $1100 \mathrm{pptv}$ in summer, $75.6 \mathrm{pptv}$ in autumn, and $733 \mathrm{pptv}$ in winter. CMAQ simulated a maximum of 373 pptv at that location, while GEOS-Chem predicted $458 \mathrm{pptv}$. Sommariva et al. (2018) also reported measurements of $\mathrm{ClNO}_{2}$ in Leicester with a maximum value of 274 pptv in spring, 74.2 pptv in summer, and 248 pptv in winter, with a peak value at Penlee Point of 922 pptv. CMAQ predicted a maximum of $274 \mathrm{pptv}$ in Leicester and $319 \mathrm{pptv}$ at Penlee Point. Eger et al. (2019) conducted shipborne observations of $\mathrm{ClNO}_{2}$ in the Mediterranean Sea and reported up to 600 pptv $\mathrm{ClNO}_{2}$ during their campaign, which is similar to the prediction of the present study.

The observed levels of $\mathrm{HCl}$ in Europe range from $<100$ to 5000 pptv (Hossaini et al., 2016, and the references therein). The CMAQ model predicted monthly average concentrations of $\mathrm{HCl}$ of 6.3 to $1249 \mathrm{pptv}$, which is similar to the observation ranges. GEOS-Chem (Sherwen et al., 2017) predicted a maximum of $12 \mathrm{pptv}$ for $\mathrm{HCl}$, which is significantly lower than the measurements in Europe.

$\mathrm{BrO}$ measurements have been reported at ground-based sites and during the ship cruises, which generally demonstrate a range of 0.5 to $2.0 \mathrm{pptv}$ maximum values for land measurements and 3.0 to $3.6 \mathrm{pptv}$ for ship measurements (Saiz-Lopez and von Glasow, 2012). BrO observations have been reported at several coastal sites in Europe. BrO levels of up to $6.5 \mathrm{pptv}$ (Saiz-Lopez et al., 2004) and $7.5 \mathrm{pptv}$ (Mahajan et al., 2009) were reported in Mace Head and Brittany, respectively. CMAQ predicts 10.1 and $0.4 \mathrm{pptv}$ at those locations, which are lower than the measurements. Sherwen et al. (2017) also predicted small values, with a maximum of 0.8 pptv in Mace Head and 0.5 pptv in Brittany. An extremely high level of $\mathrm{BrO}, \sim 100 \mathrm{pptv}$, was observed over the Dead Sea (Matveev et al., 2001; Holla et al., 2015). CMAQ is not able to reproduce such a high level of $\mathrm{BrO}$ due to the lower bromide content in typical ocean water (which was used in the present study for the Dead Sea) compared to the exceptionally high bromide content in the Dead Sea (Tas et al., 2006; Sarwar et al., 2015). 
Table 2. Simulated average concentrations of inorganic halogen species over the ocean.

\begin{tabular}{lrrlrrrrr}
\hline Species & $\begin{array}{r}\text { Concentration } \\
(\mathrm{ppt})\end{array}$ & $\begin{array}{r}\text { Percentage } \\
(\%)\end{array}$ & $\begin{array}{r}\text { Species } \\
\mathrm{HCl}\end{array}$ & $\begin{array}{r}\text { Concentration } \\
(\mathrm{ppt})\end{array}$ & $\begin{array}{r}\text { Percentage } \\
(\%)\end{array}$ & $\begin{array}{r}\text { Species } \\
\text { Concentration } \\
(\mathrm{ppt})\end{array}$ & $\begin{array}{r}\text { Percentage } \\
(\%)\end{array}$ \\
\hline $\mathrm{ClNO} 2$ & 247.9 & 96.1 & $\mathrm{HOBr}$ & 1.06 & 27.0 & $\mathrm{HOI}$ & 5.1 & 52.0 \\
$\mathrm{HOCl}$ & 4.9 & 1.9 & $\mathrm{BrCl}$ & 0.71 & 18.2 & $\mathrm{INO}_{3}$ & 2.8 & 28.7 \\
$\mathrm{ClNO}_{3}$ & 3.8 & 1.5 & $\mathrm{BrNO}_{3}$ & 0.67 & 16.9 & $\mathrm{IO}$ & 1.0 & 10.3 \\
$\mathrm{ClO}$ & 1.2 & 0.5 & $\mathrm{HBr}$ & 0.66 & 16.8 & $\mathrm{I}$ & 0.4 & 4.0 \\
$\mathrm{Cl}$ & 0.25 & 0.1 & $\mathrm{BrO}$ & 0.38 & 9.7 & $\mathrm{I}_{2} \mathrm{O}_{3}$ & 0.3 & 3.1 \\
$\mathrm{Cl}$ & 0.02 & 0.008 & $\mathrm{Br}_{2}$ & 0.33 & 8.4 & $\mathrm{HI}$ & 0.1 & 1.0 \\
- & 0.0002 & 0.0001 & $\mathrm{BrNO}_{2}$ & 0.09 & 2.4 & $\mathrm{I}_{2}$ & 0.05 & 0.5 \\
- & & & $\mathrm{Br}$ & 0.03 & 0.7 & $\mathrm{INO}_{2}$ & 0.03 & 0.3 \\
- & & & - & & & $\mathrm{I}_{2} \mathrm{O}_{2}$ & 0.01 & 0.1 \\
- & & & - & & & $\mathrm{INO}_{2}$ & 0.01 & 0.1 \\
\hline Total Cl & & & - & & & $\mathrm{I}_{2} \mathrm{O}_{4}$ & 0.004 & $<0.1$ \\
\hline
\end{tabular}
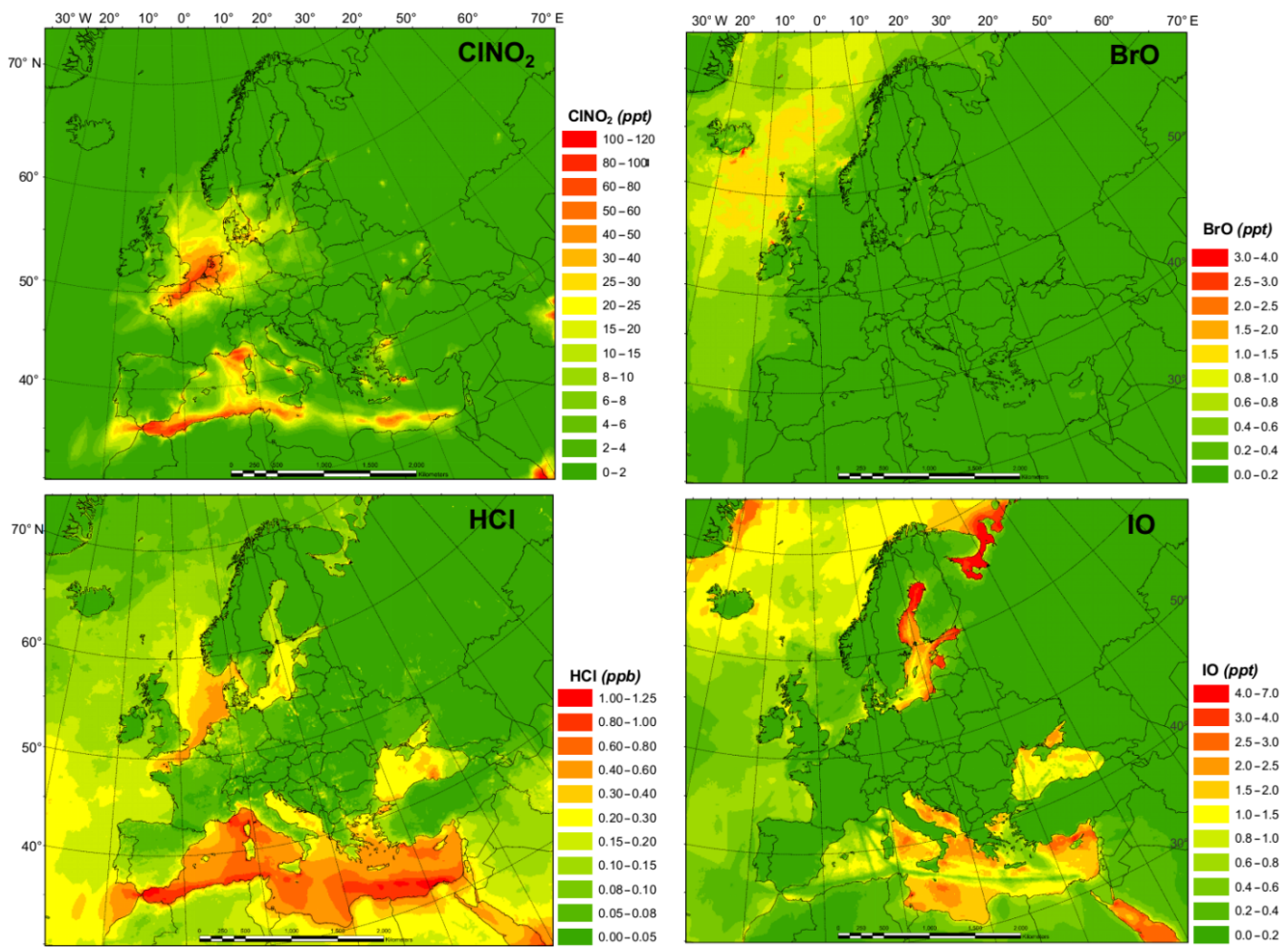

Figure 2. Monthly average $\mathrm{ClNO}_{2}, \mathrm{HCl}, \mathrm{BrO}$, and $\mathrm{IO}$ concentration in the $\mathrm{HAL}$ simulation.

Global measurements show that the IO levels observed by ground-based campaigns were generally between 0.2 and 2.4 pptv, while those by ship measurement were $\sim 3.5 \mathrm{pptv}$ (Saiz-Lopez and von Glasow, 2012). Observations of IO have also been conducted in Europe. Maximum IO levels of 4.0-50.0 pptv were measured at Mace Head (Allan et al., 2000; Commane et al., 2011). CMAQ predicts a value of 3.9 pptv at Mace Head, while GEOS-Chem predicted a value of $0.6 \mathrm{pptv}$ (Sherwen et al., 2017). In Brittany, up to 7.7-30.0 pptv of IO were observed by Bitter et al. (2005) and
Furneaux et al. (2010). CMAQ predicts $1.1 \mathrm{pptv}$ of IO at Brittany and Sherwen et al. (2017) predicted 0.07 pptv. A maximum IO concentration of $2.0 \mathrm{pptv}$ was reported in Dagebüll (Peters et al., 2005), and CMAQ predicts $9.0 \mathrm{pptv}$ at that site, while GEOS-Chem predicted 1.8 pptv (Sherwen et al., 2017). Prados-Roman et al. (2015) reported the level of IO during a ship-based campaign in the range of $<0.4$ to $>1.4 \mathrm{pptv}$ (daytime average) around the globe and 0.4 to $0.5 \mathrm{pptv}$ (daytime average) in the south of Spain and the west of Africa 
Table 3. Comparison of observed and simulated halogen species.

\begin{tabular}{|c|c|c|c|}
\hline Location & Species & Observation $^{\mathrm{a}}$ & Simulation $^{\mathrm{b}}$ \\
\hline Hessen, Germany ${ }^{\mathrm{c}}$ & $\mathrm{ClNO}_{2}$ & 800.0 & 273.4 \\
\hline London, United Kingdom ${ }^{\mathrm{d}}$ & $\mathrm{ClNO}_{2}$ & 724.0 & 801.5 \\
\hline Weybourne, United Kingdom ${ }^{\mathrm{e}}$ & $\mathrm{ClNO}_{2}$ & 65 & 373 \\
\hline Weybourne, United Kingdom ${ }^{\mathrm{f}}$ & $\mathrm{ClNO}_{2}$ & 946 & 373 \\
\hline Weybourne, United Kingdom ${ }^{\mathrm{g}}$ & $\mathrm{ClNO}_{2}$ & 1100 (summer), 75.6 (autumn), 733 (winter) & 373 \\
\hline Leicester, United Kingdom ${ }^{\mathrm{g}}$ & $\mathrm{ClNO}_{2}$ & 274 (spring), 74.2 (summer), 248 (winter) & 274 \\
\hline Penlee Point, United Kingdom ${ }^{\mathrm{g}}$ & $\mathrm{ClNO}_{2}$ & 922 & 319 \\
\hline Mace Head, Ireland ${ }^{\mathrm{h}}$ & $\mathrm{BrO}$ & 6.5 & 10.1 \\
\hline Brittany, France ${ }^{\mathrm{i}}$ & $\mathrm{BrO}$ & 7.5 & 0.4 \\
\hline Dead Sea ${ }^{j}$ & $\mathrm{BrO}$ & 100.0 & 0.2 \\
\hline Mace Head, Ireland ${ }^{\mathrm{k}}$ & IO & $4.0-50.0$ & 3.9 \\
\hline Brittany, France ${ }^{1}$ & $\mathrm{IO}$ & $7.7-30.0$ & 1.1 \\
\hline Dagebüll, Germany ${ }^{\mathrm{m}}$ & $\mathrm{IO}$ & 2.0 & 9.0 \\
\hline Atlantic Ocean ${ }^{\mathrm{n}}$ & $\mathrm{IO}$ & 0.4 to 0.5 (daytime average) & 0.4 to 2.0 (daytime average) \\
\hline
\end{tabular}

(over the Atlantic); the present study predicted 0.4 to 2.0 pptv (daytime average) of IO over those areas.

\subsection{Influence of halogen chemistry on the atmospheric oxidation capacity}

Figure 3 shows the monthly average concentrations of the $\mathrm{OH}$ and $\mathrm{HO}_{2}$ radicals predicted by the BASE simulation as well as the impact of chlorine chemistry (CL-BASE) and the full halogen chemistry (HAL-BASE) on the simulated $\mathrm{OH}$ and $\mathrm{HO}_{2}$ levels. In the BASE simulation, the highest $\mathrm{OH}$ concentration levels are predicted over the oceans, especially along ship tracks, with a maximum value of 0.38 pptv $\left(\sim 9.5 \times 10^{6}\right.$ molecule $\left.\mathrm{cm}^{-3}\right)$. The chlorine chemistry slightly increased the $\mathrm{OH}$ level over most of the domain by up to $0.0041 \mathrm{pptv}\left(1.0 \times 10^{5}\right.$ molecule $\left.\mathrm{cm}^{-3}\right)$. The impact of the halogen chemistry has competing effects on $\mathrm{OH}$ concentrations, with a maximum increase of $0.030 \mathrm{pptv}$ $\left(7.5 \times 10^{5}\right.$ molecule $\left.\mathrm{cm}^{-3}\right)$ and a reduction of as much as 0.023 pptv $\left(5.8 \times 10^{5}\right.$ molecule $\left.\mathrm{cm}^{-3}\right)$. The BASE simulation predicts the highest values of $\mathrm{HO}_{2}$ over the Mediterranean Sea, with a maximum value of 21 pptv. The chlorine chemistry increases the $\mathrm{HO}_{2}$ level in the areas of elevated $\mathrm{ClNO}_{2}$ predictions (Figs. 2 and 3). The further addition of halogen chemistry lowers the $\mathrm{HO}_{2}$ as much as $3.7 \mathrm{pptv}$ and increases $\mathrm{HO}_{2}$ up to 0.73 pptv compared to the BASE simulation. The overall difference of $\mathrm{HO}_{2}$ because of halogens was $-0.59 \mathrm{pptv}$ in the European domain. The effect of halogen chemistry on $\mathrm{OH}$ and $\mathrm{HO}_{2}$ is the combined effect of the following four pathways: (1) conversion of $\mathrm{HO}_{2}$ to $\mathrm{OH}$ via $\mathrm{XO}$ (Reactions R5 and R6), in which $\mathrm{HO}_{2}$ decreases and $\mathrm{OH}$ increases; (2) reduction of $\mathrm{O}_{3}$ (Reaction $\mathrm{R} 1$ and Fig. 7) and the reduced production of $\mathrm{OH}$ by $\mathrm{O}_{3}$ photolysis, in which both
$\mathrm{OH}$ and $\mathrm{HO}_{2}$ decrease; (3) increase in $\mathrm{NO}_{2}$ (Reaction R4 and Fig. 7) and the enhanced consumption of $\mathrm{OH}$ by the reaction with $\mathrm{NO}_{2}$, in which both $\mathrm{OH}$ and $\mathrm{HO}_{2}$ decrease; and (4) increased oxidation of VOCs due to halogens in which both $\mathrm{OH}$ and $\mathrm{HO}_{2}$ increase. Pathway (1) leads to the increase in $\mathrm{OH}$ and decrease in $\mathrm{HO}_{2}$ over coastal areas, the Mediterranean Sea, and the Baltic Sea (except the ship tracks). Pathway (2) results in a decrease in $\mathrm{OH}$ and $\mathrm{HO}_{2}$ over the remote ocean. Pathways (2), (3), and (4) result in a decrease in $\mathrm{OH}$ and an increase or decrease in $\mathrm{HO}_{2}$ along the ship tracks in the Mediterranean Sea.

Sarwar et al. (2015) reported a small overall decrease in $\mathrm{OH}(1 \%)$ and a significant decrease in $\mathrm{HO}_{2}(11 \%)$ in the Northern Hemisphere due to bromine and iodine chemistry. Their results suggest a considerable reduction of the $\mathrm{HO}_{2} / \mathrm{OH}$ ratio, which is consistent with the present study. Muñiz-Unamunzaga et al. (2018) found a slight increase in diurnal $\mathrm{OH}(1 \%-2 \%)$ and a noticeable decrease in $\mathrm{HO}_{2}$ (4\%), leading to a decrease in $\mathrm{HO}_{2} / \mathrm{OH}$ in Los Angeles, California. Sherwen et al. (2017) suggested that $\mathrm{OH}$ was reduced across their European domain due to halogen chemistry and concluded that the shift of $\mathrm{HO}_{2}$ to $\mathrm{OH}$ by XO could not compensate for the decrease in $\mathrm{OH}$ due to the loss of $\mathrm{O}_{3}$. Another GEOS-Chem study, however, predicted an increase in $\mathrm{OH}$ over the Mediterranean Sea (Stone et al., 2018). The discrepancy among previous studies and between those works and the present one is difficult to deduce and requires further investigation. Several possible causes could lead to different simulated levels of halogens and their impact on oxidants, including the different mechanisms of producing and recycling halogen species (Sarwar et al., 2019), spatial resolution (Sommariva et al., 2018), emission inventory (Wang 

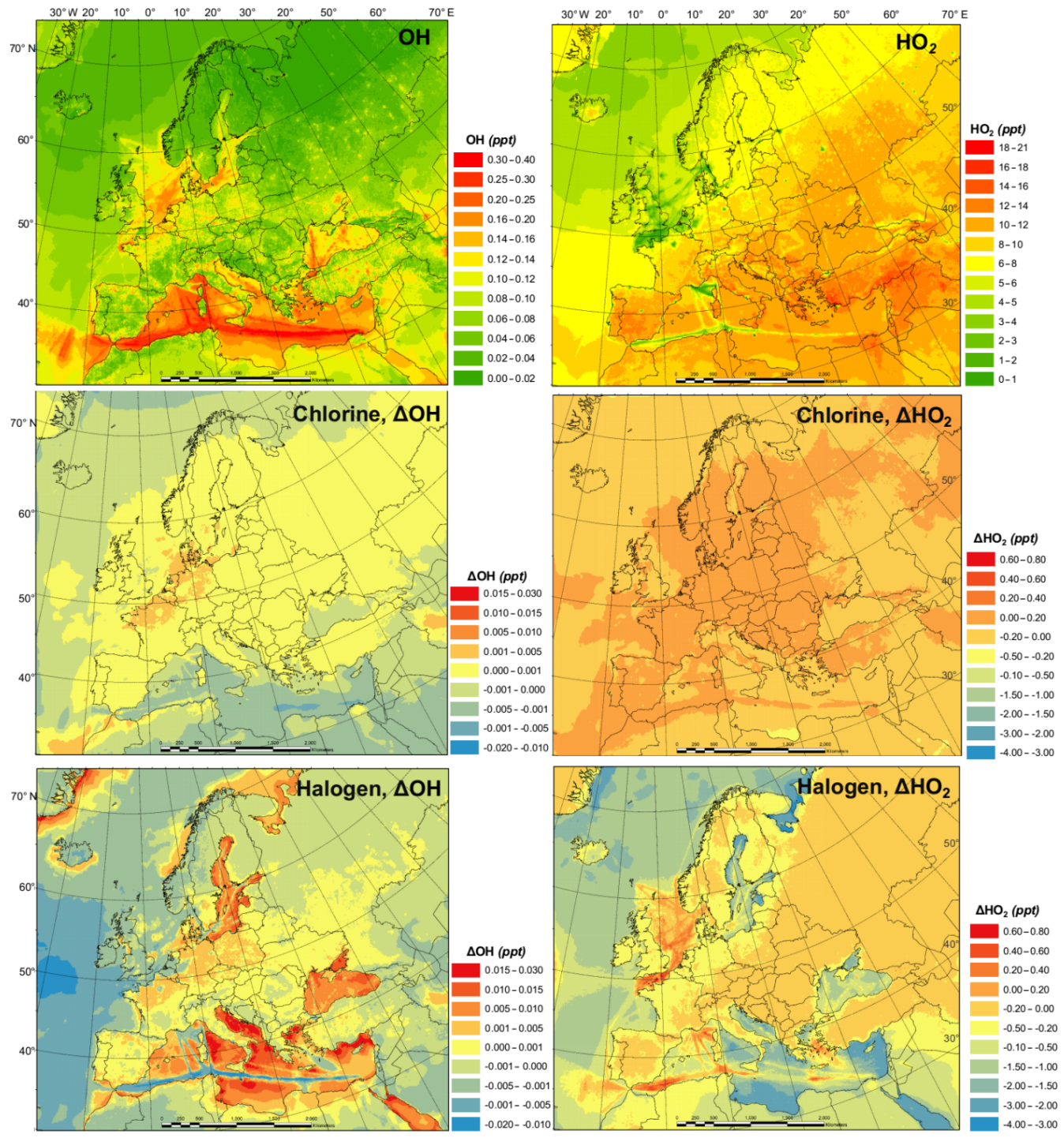

Figure 3. Monthly average $\mathrm{OH}$ and $\mathrm{HO}_{2}$ concentration in the BASE simulation and changes due to chlorine (CL) and full halogen chemistry (HAL).

et al., 2019), and different spatiotemporal scale of interest (Stone et al., 2018).

Figure 4 presents the monthly average prediction of $\mathrm{NO}_{3}$ and $\mathrm{Cl}$ radicals in the BASE scenario and the influence of chlorine (CL-BASE) and halogen chemistry (HAL-BASE) on the levels of $\mathrm{NO}_{3}$ and $\mathrm{Cl}$. The BASE simulation predicted relatively high $\mathrm{NO}_{3}$ concentrations over the Mediterranean Sea along the busy shipping tracks. Although concentrations as high as $71 \mathrm{pptv}$ are found, the majority of oceanic regions have concentrations in the range of 10 to $40 \mathrm{pptv}$ and between 0 and $4 \mathrm{pptv}$ over land. The chlorine chemistry slightly increases the $\mathrm{NO}_{3}$ radical due to the increase in $\mathrm{O}_{3}$ (see Sect. 3.4). In contrast, the halogen chemistry considerably reduces $\mathrm{NO}_{3}$ concentrations by as much as $20 \mathrm{pptv}$ in the nighttime over the Mediterranean Sea. Muñiz-Unamunzaga et al. (2018) reported a 20\%-50\% ( 2 to 4 pptv) decrease in the $\mathrm{NO}_{3}$ radical in Los Angeles, California, when considering the halogen chemistry.

In the BASE simulation, the $\mathrm{Cl}$ concentration was negligible because there was no relevant chlorine source incorporated in the CMAQ model. The CL simulation contains the production of $\mathrm{ClNO}_{2}$ and its subsequent photolysis, which increases the $\mathrm{Cl}$ concentration to as high as $7.0 \times 10^{-4} \mathrm{pptv}$ $\left(\sim 1.75 \times 10^{4}\right.$ atom $\left.\mathrm{cm}^{-3}\right)$. The HAL simulation predicted a very similar magnitude and spatial distribution of chlorine concentration. Sherwen et al. (2017) reported $\mathrm{Cl}$ concentrations less than $1.4 \times 10^{4}$ atom $\mathrm{cm}^{-3}\left(\sim 5.6 \times 10^{-4} \mathrm{pptv}\right)$ over Europe, comparable to our prediction. Hossaini et al. (2016) reported more than $1.0 \times 10^{4}$ atom $\mathrm{cm}^{-3}\left(\sim 4.0 \times 10^{-4} \mathrm{pptv}\right)$ of chlorine over Asia, Europe, and North America, with a maximum of $8.5 \times 10^{4}$ atom $\mathrm{cm}^{-3}\left(\sim 3.4 \times 10^{-3} \mathrm{pptv}\right)$, using a global chemical transport model (TOMCAT) that in- 

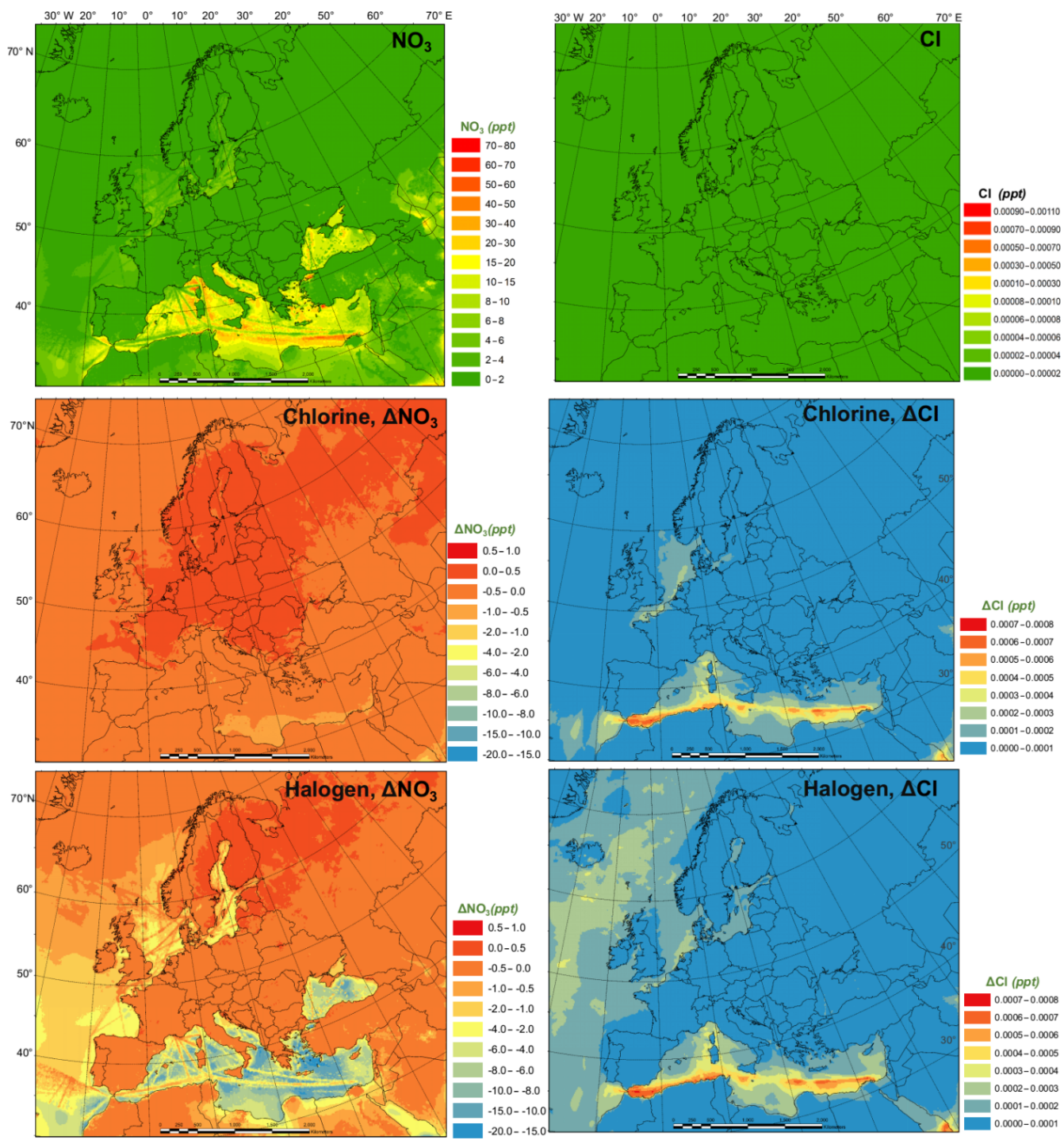

Figure 4. Monthly average $\mathrm{NO}_{3}$ and $\mathrm{Cl}$ radical concentrations in the BASE simulation and changes induced by chlorine (CL) and full halogen chemistry (HAL).

corporated chlorine sources from sea salt dechlorination, coal and biomass burning, oxidation of natural and anthropogenic chlorocarbon, and heterogeneous reactions on sea salt and sulfate aerosol. In their study, Hossaini et al. (2016) used the Reactive Emission Inventory of Chlorine (Keene et al., 1999), which Wang et al. (2019) reported to be unrealistic for present-day applications.

The current study and previous studies simulated a broad range of surface $\mathrm{Cl}$ concentrations, although they were all within the scope of the reported observed (observation-based calculation) values of $10^{3}$ to $10^{5}$ atom cm ${ }^{-3}\left(\sim 4.0 \times 10^{-5}\right.$ to $4.0 \times 10^{-3}$ pptv) according to the review of Saiz-Lopez and von Glasow (2012). In light of the considerable variation of observed and model-predicted $\mathrm{Cl}$ levels, further study may be needed to comprehensively evaluate the significant role of $\mathrm{Cl}$ in the troposphere.
Figures 5 and 6 demonstrate the monthly average of the daily maximum concentrations of $\mathrm{OH}, \mathrm{HO}_{2}, \mathrm{NO}_{3}$, and $\mathrm{Cl}$ in the BASE simulation and also the impact of chlorine (CLBASE) and the halogen chemistry (HAL-BASE). The maximum values of $\mathrm{OH}, \mathrm{HO}_{2}$, and $\mathrm{Cl}$ were predicted during the daytime, but they peak at different hours with $\mathrm{Cl}$ in the early morning and $\mathrm{OH}$ and $\mathrm{HO}_{2}$ later in the day, while the highest levels of the $\mathrm{NO}_{3}$ radical were simulated during nighttime.

The monthly averages of the daily maxima of $\mathrm{OH}, \mathrm{HO}_{2}$, $\mathrm{NO}_{3}$, and $\mathrm{Cl}$ (Figs. 5 and 6) have similar spatial patterns and higher concentrations (or changes in concentration) compared to those of the monthly averages (Figs. 3 and 4). The monthly average of the daily maximum $\mathrm{OH}\left(\mathrm{HO}_{2}\right.$ and $\mathrm{NO}_{3}$ ) radical is 3.7 (2.5 and 3.4) times the monthly average $\mathrm{OH}\left(\mathrm{HO}_{2}\right.$ and $\left.\mathrm{NO}_{3}\right)$ concentration in the BASE simulations, while both the monthly average of the daily maximum and 

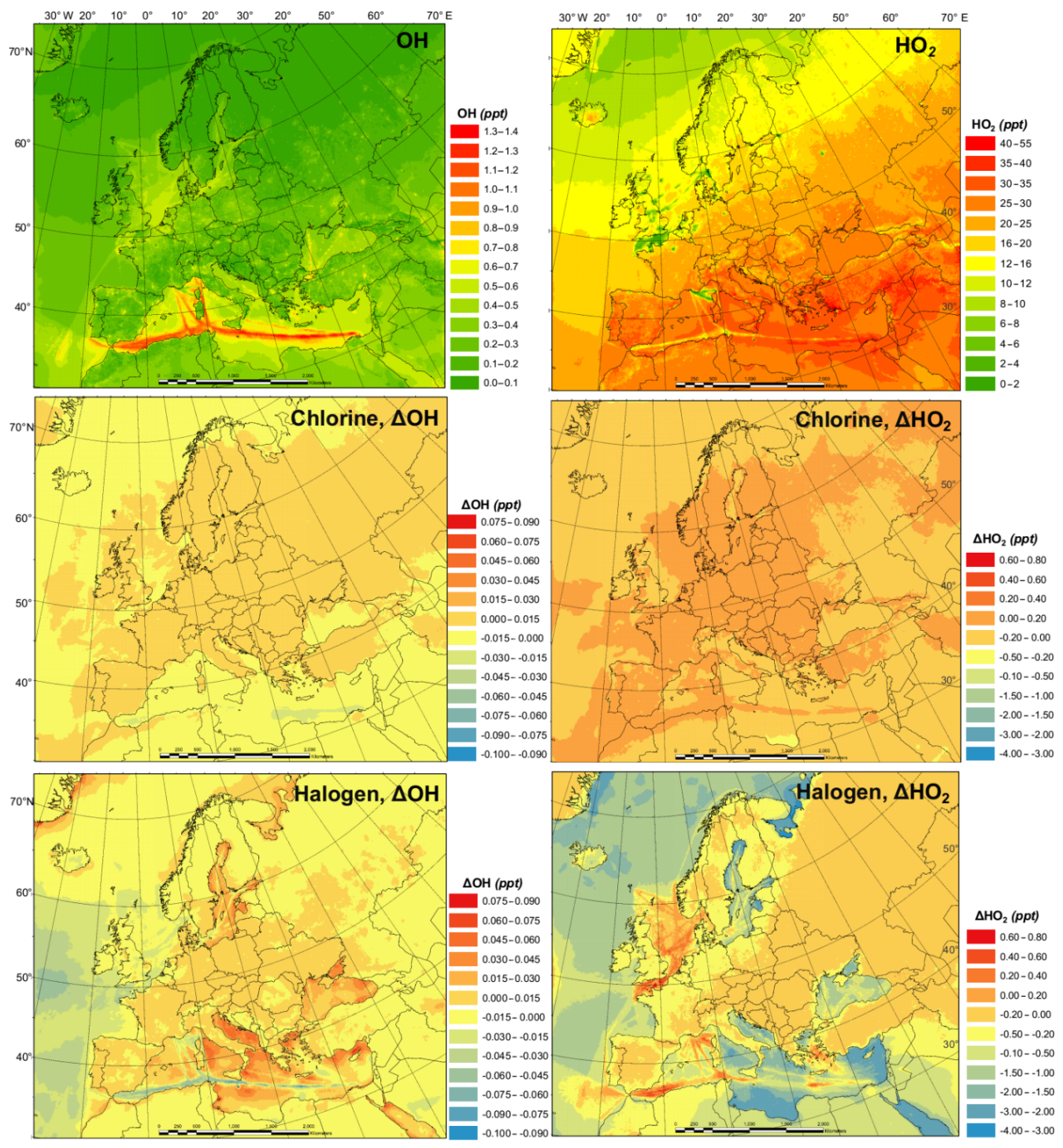

Figure 5. Monthly average of daily maximum concentrations of $\mathrm{OH}$ and $\mathrm{HO}_{2}$ in the BASE simulation and changes due to chlorine (CL) and full halogen chemistry (HAL).

monthly average $\mathrm{Cl}$ show negligible values. The monthly average of daily maximum changes in the $\mathrm{OH}\left(\mathrm{HO}_{2}\right)$ concentration due to the chlorine and halogen chemistry has a magnitude of -0.10 to $0.09 \mathrm{pptv}$ ( -4.0 to $0.8 \mathrm{pptv}$ ), which is wider than (the same as) that of the monthly averages, i.e., -0.020 to 0.03 pptv ( -4.0 to 0.8 pptv). For the $\mathrm{NO}_{3}$ (Cl) radicals, the magnitude of changes in the monthly average is -20 to $1.0 \mathrm{pptv}$ ( 0.0 to $0.0008 \mathrm{pptv}$ ), while that in the monthly average of daily maximums is -55 to $1.0 \mathrm{pptv}$ ( 0.0 to $0.0055 \mathrm{pptv}$ ).

We also examine the diurnal variations of the four radicals in the BASE and HAL scenarios (Figs. S3 and S4). Halogens have a small effect on the diurnal pattern of $\mathrm{OH}$. $\mathrm{HO}_{2}$ is reduced by halogens, especially in the midday. The $\mathrm{NO}_{3}$ radical is strongly decreased throughout the night after the addition of halogens. The $\mathrm{Cl}$ atom is released by the halogen chemistry in the early morning. The significant effects of halogen chemistry on the diurnal variation of $\mathrm{OH}, \mathrm{HO}_{2}$, $\mathrm{NO}_{3}$, and $\mathrm{Cl}$ radicals highlight the role of halogen chemistry in regulating the atmospheric oxidation capacity throughout the day, with the highest effect on $\mathrm{Cl}$ in the early morning, maximum effects on $\mathrm{OH}$ and $\mathrm{HO}_{2}$ in daytime, and the largest effect on $\mathrm{NO}_{3}$ at night.

\subsection{Impact of halogen chemistry on regulated gaseous air pollutants}

The monthly average modeled $\mathrm{NO}_{2}$ and $\mathrm{O}_{3}$, two major gaseous air pollutants in Europe, and the effect of chlorine and halogen chemistry on the two regulated gaseous species are shown in Fig. 7. The BASE simulation produced 

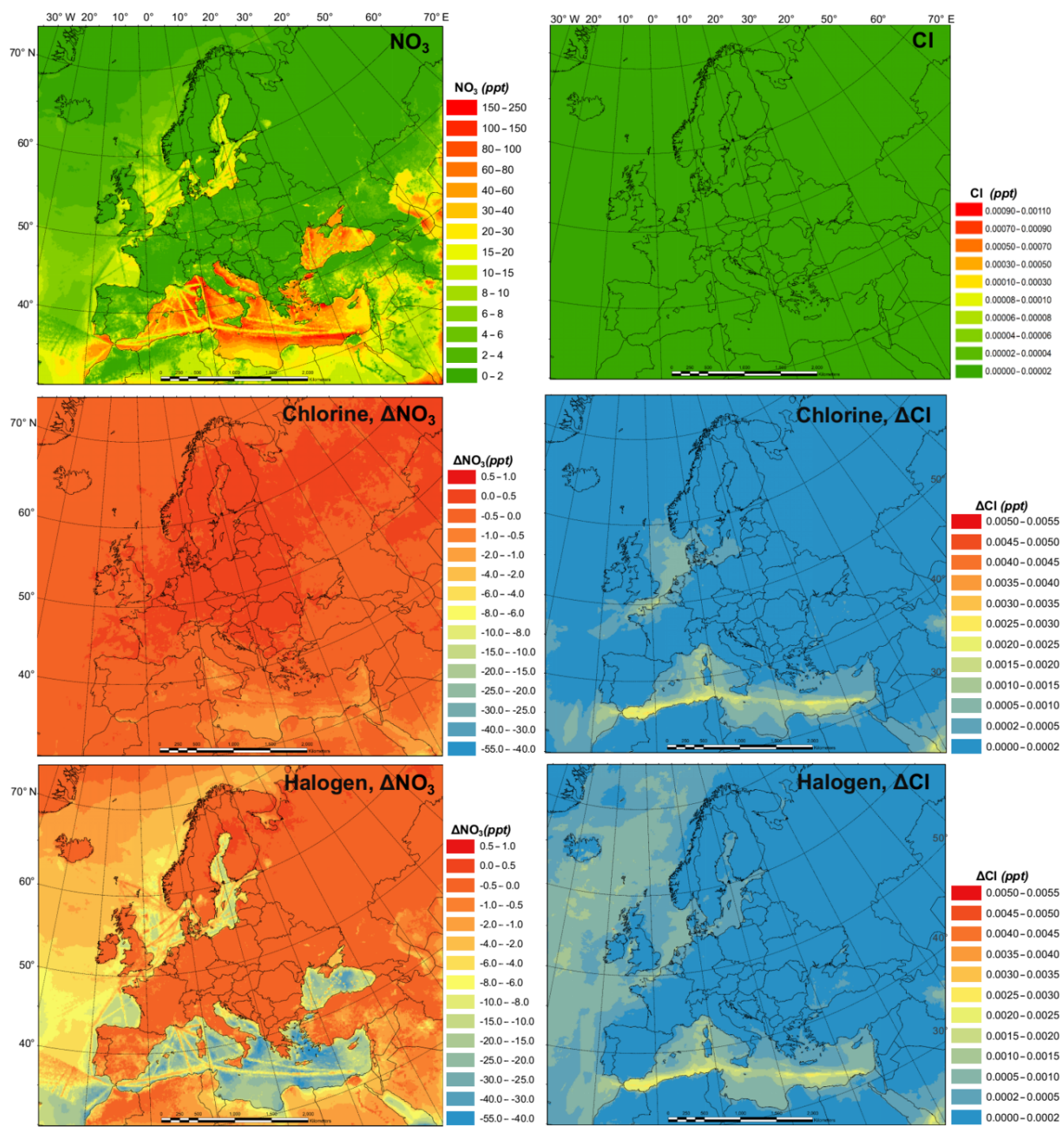

Figure 6. Monthly average of daily maximum concentrations of $\mathrm{NO}_{3}$ and the $\mathrm{Cl}$ radical in the BASE simulation and changes induced by chlorine (CL) and full halogen chemistry (HAL).

many hot spots of $\mathrm{NO}_{2}$ over Europe in the vicinity of major cities and ship trajectories. The chlorine chemistry slightly increases the level of $\mathrm{NO}_{2}$ (by up to $0.038 \mathrm{ppbv}$ ) in the majority of the domain since (1) the production and the subsequent photolysis of $\mathrm{ClNO}_{2}$ recycles the $\mathrm{NO}_{x}$ and extends its lifetime, which increases both $\mathrm{NO}_{2}$ and $\mathrm{NO}$ (Figs. 7 and S5), and (2) the increased $\mathrm{O}_{3}$ level (Fig. 7) enhances the transformation of $\mathrm{NO}$ to $\mathrm{NO}_{2}$, which increases $\mathrm{NO}_{2}$ and decreases NO (Figs. 7 and S2). Some grid cells show a decrease in $\mathrm{NO}_{2}$ (as much as $0.09 \mathrm{ppbv}$ ) because the enhanced oxidative capacity (Sect. 3.3) promotes the cleansing of $\mathrm{NO}_{2}$ via $\mathrm{OH}$, forming $\mathrm{HNO}_{3}$. The full halogen chemistry enhances $\mathrm{NO}_{2}$ (up to $0.20 \mathrm{ppbv}$ ) over the North Sea and the Mediterranean Sea and decreases $\mathrm{NO}_{2}$ (by as much as $1.7 \mathrm{ppbv}$ ) in the most polluted hot spots. The increase in $\mathrm{NO}_{2}$ occurs through the reactions of XO with NO. Meanwhile, in the most polluted regions, the $\mathrm{NO}-\mathrm{NO}_{2}$ balance is predominantly controlled by the reactions of $\mathrm{NO}$ with $\mathrm{HO}_{2}$ and $\mathrm{O}_{3}$. With the decrease in $\mathrm{HO}_{2}$ and $\mathrm{O}_{3}$ due to the halogen chemistry, the transformation of $\mathrm{NO}$ to $\mathrm{NO}_{2}$ is reduced, which leads to decreasing $\mathrm{NO}_{2}$ and increasing NO.

The monthly average $\mathrm{O}_{3}$ concentration over Europe from the BASE simulation was relatively high (up to $57 \mathrm{ppbv}$ ), especially over southern Europe where higher temperatures and more intensive radiation promote the formation of this secondary pollutant. Chlorine chemistry increases $\mathrm{O}_{3}$ levels over the land of Europe with a maximum increment of $0.22 \mathrm{ppbv}$ and decreases $\mathrm{O}_{3}$ over the oceanic area by as much as $0.76 \mathrm{ppbv}$. The full halogen chemistry decreases $\mathrm{O}_{3}$ throughout the domain, with a maximum reduction of 10 ppbv. On average, the halogen chemistry reduces the $\mathrm{O}_{3}$ concentration by more than $3.0 \mathrm{ppbv}$ in coastal Europe and 

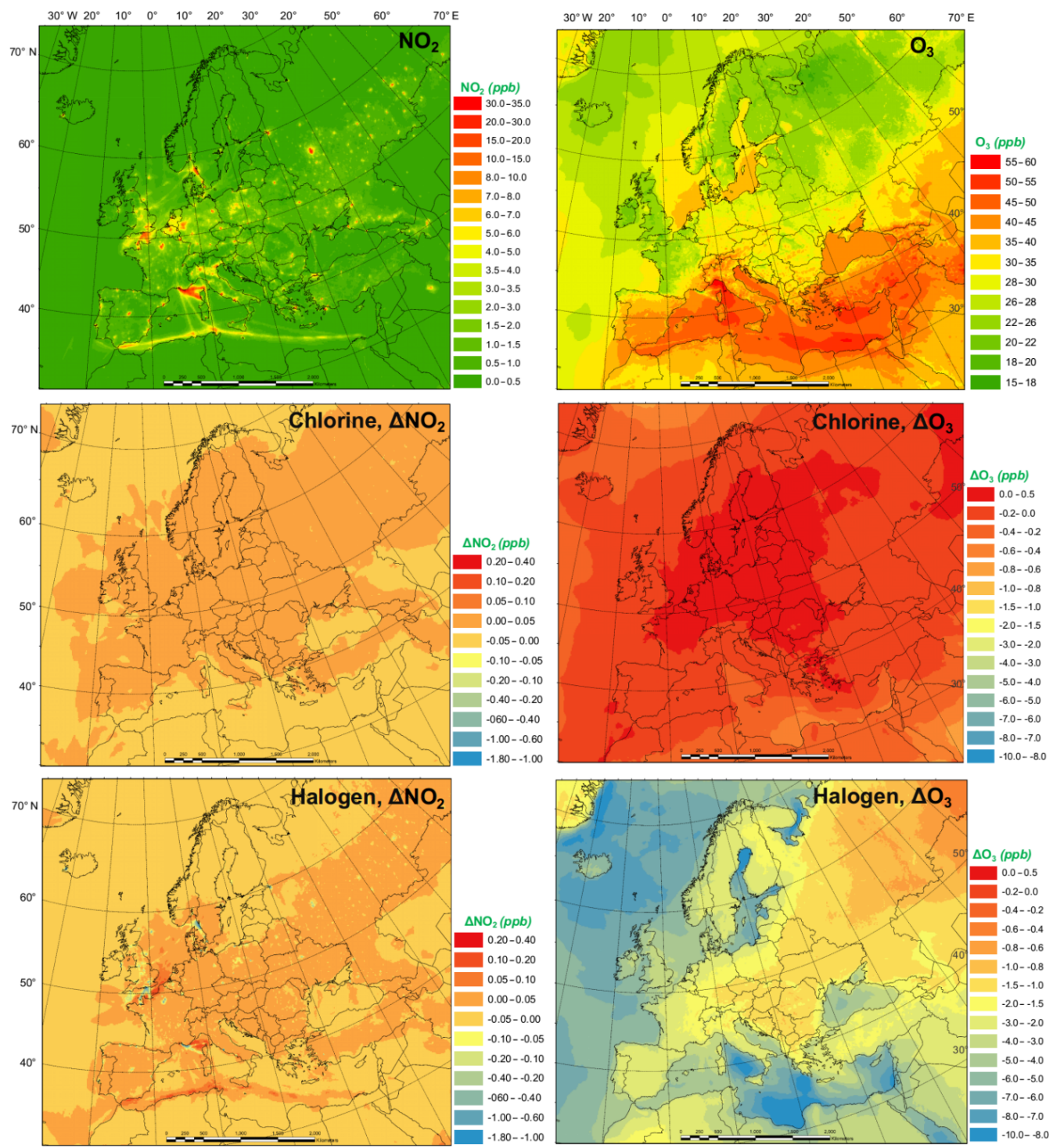

Figure 7. Monthly average $\mathrm{NO}_{2}$ and $\mathrm{O}_{3}$ concentration in the BASE simulation and changes induced by chlorine (CL) and full halogen chemistry (HAL).

by over $2.0 \mathrm{ppbv}$ over western and central Europe (nearly $1000 \mathrm{~km}$ from the ocean). Our model simulation highlights the fact that halogen chemistry has a large impact on $\mathrm{O}_{3}$ concentrations over oceanic areas and a moderate impact on $\mathrm{O}_{3}$ over coastal and continental regions of Europe.

Muñiz-Unamunzaga et al. (2018) reported a decrease of $-2.0 \mathrm{ppbv} \mathrm{O}_{3}$ in the inland areas of the western US (several hundred kilometers from the ocean) and a reduction of 2.5 to $5.0 \mathrm{ppbv} \mathrm{O}_{3}$ in the coastal regions due to the full halogen chemistry. Sarwar et al. (2015) suggested that the inclusion of halogen processes reduced $\mathrm{O}_{3}$ concentrations by 2.0 to $4.0 \mathrm{ppbv}$ over most of the terrestrial regions in the Northern Hemisphere and over $6.0 \mathrm{ppbv}$ in some coastal areas. Sherwen et al. (2017) used a revised version of GEOS-Chem (Sherwen et al., 2016) with halogen chemistry to show sub- stantial reductions in $\mathrm{O}_{3}$ over Europe, with an average reduction of $13.5 \mathrm{ppbv}$ in the domain and a maximum of $28.9 \mathrm{ppbv}$ in some locations.

\subsection{Implications for policy assessment}

The current air quality management in Europe has two main objectives: (1) to protect human health and (2) to protect the environment. While many plans and measures have prioritized particulate matter (PM) or $\mathrm{NO}_{2}$, policies to reduce $\mathrm{O}_{3}$ concentrations are still needed (EEA, 2018a). The World Health Organization (WHO) Air Quality Guidelines value for $\mathrm{O}_{3}$ (maximum daily $8 \mathrm{~h}$ mean of $100 \mu \mathrm{g} \mathrm{m}^{-3}$ ) was exceeded in $96 \%$ of all the reporting stations in Europe, although this is especially true for areas near the Mediterranean 

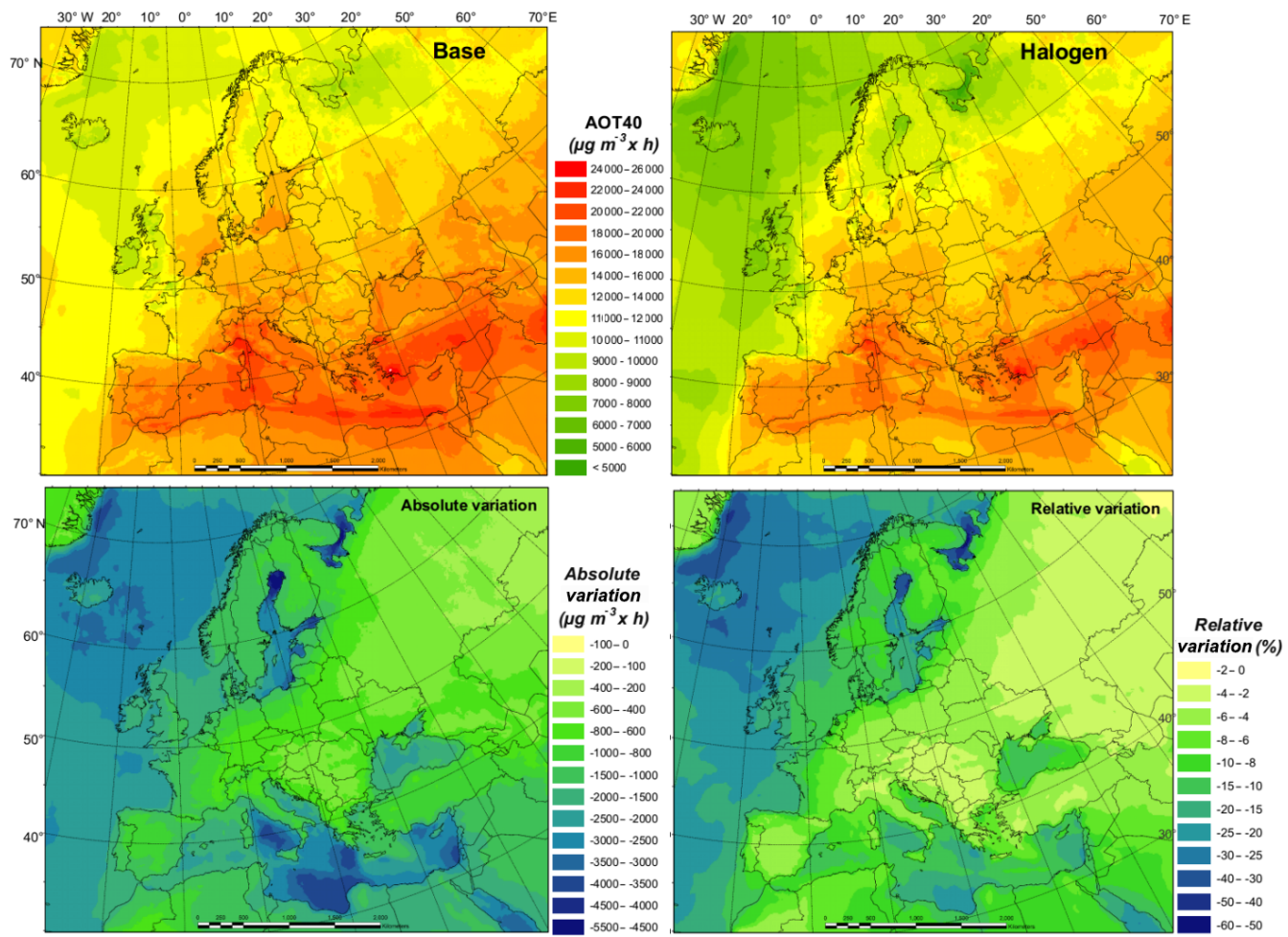

Figure 8. AOT40 for July in the BASE and HAL simulations and absolute and relative changes between the two simulations.

Sea. According to the European Environment Agency's latest report, $12 \%$ of the EU-28 urban population is exposed to $\mathrm{O}_{3}$ concentrations above the European Union target value threshold (a maximum daily $8 \mathrm{~h}$ mean of $120 \mu \mathrm{g} \mathrm{m}^{-3}$ is not to be exceeded on more than $25 \mathrm{~d} \mathrm{yr}^{-1}$, as set out by the Directive 2008/50/EC) in 2016. Apart from significant potential health effects (Jerrett et al., 2009; Malley et al., 2017), $\mathrm{O}_{3}$ is also known to have a negative impact on vegetation (Mills et al., 2011). The target value for the protection of vegetation (18000 $\mu^{-3} \mathrm{~m}^{-3} \mathrm{~h}^{-1}$ accumulated over May to July), based on the AOT40 index (Accumulated Ozone exposure over a Threshold of $40 \mathrm{ppbv}$ ), was exceeded for about $31 \%$ of all agricultural land in all European countries. The critical level for this pollutant $\left(10000 \mu \mathrm{g} \mathrm{m}^{-3} \mathrm{~h}^{-1}\right.$ accumulated over April to September) was exceeded in $60 \%$ of the total forest area of the continent in 2016 (EEA, 2018a).

Since our experiment covers only 1 month, it is not possible to assess the impact of halogen chemistry on these two indexes. Nonetheless, we have compared the results of both maximum daily $8 \mathrm{~h}$ mean and 1-month AOT40 (over July; Fig. 8) for the BASE and HAL simulations. The relative variation provides a good indication of the potential impact of considering halogens in our modeling system in the estimation of legally relevant indexes.

We find that halogen chemistry strongly affects the ambient $\mathrm{O}_{3}$ concentration and may need to be considered in the formulation of plans and strategies for $\mathrm{O}_{3}$ non-attainment ar- eas. We see differences between BASE and HAL simulations (over land in July 2016) as high as $12 \%$ and $36 \%$ for the number of days with daily maximum $8 \mathrm{~h} \mathrm{O}_{3}$ over $120 \mu \mathrm{g} \mathrm{m}^{-3}$ and the monthly average daily maximum $8 \mathrm{~h} \mathrm{O}_{3}$ level, respectively (Figs. S6 and S7). Furthermore, we notice strong regional differences, mainly between coastal and inland areas. The considerable effect of halogen chemistry on air quality implies the need to improve the robustness and accuracy of modeling tools to design customized policies to control $\mathrm{O}_{3}$.

In Sect. 3.3 and 3.4, we have also discussed the effect of halogen chemistry on the partitioning of $\mathrm{OH} / \mathrm{HO}_{2}$ and $\mathrm{NO} / \mathrm{NO}_{2}$. The budgets of $\mathrm{HO}_{x}$ and $\mathrm{NO}_{x}$ are key parameters to accurately simulate the formation of $\mathrm{O}_{3}$ and its response to the reduction of precursors, namely $\mathrm{NO}_{x}$ and VOCs (e.g., $\mathrm{Li}$ et al., 2018). Air quality models are predominantly used to formulate air pollution control policy by examining the responses of $\mathrm{O}_{3}$ levels to various reduction rates of $\mathrm{NO}_{x}$ and/or VOCs. The models that do not include the comprehensive halogen chemistry can potentially lead to different $\mathrm{O}_{3}$ concentration responses to $\mathrm{NO}_{x}$ and/or VOC emission changes in Europe.

This study also demonstrates that chlorine chemistry affects the formation of $\mathrm{O}_{3}$. The current policy is only designed to control the long-lived chlorinated species (Hossaini et al., 2015) but not reactive chlorine species, e.g., $\mathrm{HCl}$, chloride, and short-lived chlorocarbons, from coal burn- 
ing, biomass burning, and industrial activities. The coal-fired power plants in the EU (EEA, 2018b; Kuklinska et al., 2015) can potentially provide chlorine sources, making the implications of halogen chemistry even more relevant.

\section{Conclusion}

We applied the CMAQ model with comprehensive halogen chemistry $(\mathrm{Cl}, \mathrm{Br}$, and $\mathrm{I})$ to conduct high-resolution simulations for examining the impact of halogen chemistry on air quality over Europe.

The comparison of model results with observations from over 400 monitoring sites indicates that the CMAQ model is capable of reproducing the concentrations and temporal variations of air pollutants over Europe and can be employed to study the impact of halogen chemistry in Europe. The comparison of predicted halogen species concentrations with measurements suggests that the CMAQ model is able to predict observed levels of chlorine and iodine species, although it underestimates bromine species.

Chlorine chemistry enhances the atmospheric oxidation capacity by significantly increasing the level of the $\mathrm{Cl}$ radical and affects the levels of $\mathrm{OH}, \mathrm{HO}_{2}, \mathrm{NO}_{3}, \mathrm{O}_{3}$, and $\mathrm{NO}_{2}$. The combined halogen chemistry marginally increases the level of $\mathrm{OH}$ and reduces $\mathrm{HO}_{2}, \mathrm{NO}_{3}$, and $\mathrm{O}_{3}$. The impact of halogen chemistry on the ambient concentration of $\mathrm{NO}_{2}$ is smaller but non-negligible.

Halogen chemistry significantly influences the atmospheric oxidation capacity throughout the day by imposing the highest effect on $\mathrm{Cl}$ in the early morning, maximum effects on $\mathrm{OH}$ and $\mathrm{HO}_{2}$ in daytime, and the largest effect on $\mathrm{NO}_{3}$ at night. Halogen chemistry can have a strong influence on atmospheric composition over oceanic and coastal regions but also some noticeable impacts over continental Europe. This study highlights the potential benefit of incorporating halogen chemistry into air quality models for policy development.

Although the incorporation of the halogen chemistry may improve the capabilities of 3-D Eulerian chemical transport models, we acknowledge that large uncertainties still exist in the assessment of the halogen chemistry impact due to emission inventories (e.g., chlorine emission inventory; Wang et al., 2019), model configurations (e.g., grid size; Sommariva et al., 2018), and chemical mechanisms (e.g., photolysis rate of iodine oxides, recycling rate of halogen species on aerosol; Simpson et al., 2015). Further field, laboratory, and theoretical studies are needed to constrain modeling studies for evaluating the impacts of halogen chemistry on air quality and for assessing air quality policy implications.

Data availability. The data used and demonstrated in this study are available upon the request to the corresponding author.
Supplement. The supplement related to this article is available online at: https://doi.org/10.5194/acp-19-15321-2019-supplement.

Author contributions. ASL designed the research. GS and BG conducted the CMAQ modeling. RB, DP, JD, GS, BG, QL, and ASL analyzed the results. QL, RB, GS, and ASL wrote the paper with contributions from all authors.

Competing interests. The authors declare that they have no conflict of interest.

Disclaimer. The views expressed in this paper are those of the authors and do not necessarily represent the views or policies of the U.S. EPA.

Financial support. This research has been supported by the European Commission, H2020 Research Infrastructures (CLIMAHAL (grant no. 726349)).

Review statement. This paper was edited by Michel Van Roozendael and reviewed by three anonymous referees.

\section{References}

Allan, B. J., McFiggans, G., Plane, J. M. C., and Coe, H.: Observations of iodine monoxide in the remote marine boundary layer, J. Geophys. Res., 105, 14363-14369, https://doi.org/10.1029/1999JD901188, 2000.

Appel, K. W., Chemel, C., Roselle, S. J., Francis, X. V, Hu, R.-M., Sokhi, R. S., Rao, S. T., and Galmarini, S.: Examination of the Community Multiscale Air Quality (CMAQ) model performance over the North American and European domains, Atmos. Environ., 53, 142-155, https://doi.org/10.1016/j.atmosenv.2011.11.016, 2012.

Appel, K. W., Pouliot, G. A., Simon, H., Sarwar, G., Pye, H. O. T., Napelenok, S. L., Akhtar, F., and Roselle, S. J.: Evaluation of dust and trace metal estimates from the Community Multiscale Air Quality (CMAQ) model version 5.0, Geosci. Model Dev., 6, 883-899, https://doi.org/10.5194/gmd-6-883-2013, 2013.

Appel, K. W., Napelenok, S. L., Foley, K. M., Pye, H. O. T., Hogrefe, C., Luecken, D. J., Bash, J. O., Roselle, S. J., Pleim, J. E., Foroutan, H., Hutzell, W. T., Pouliot, G. A., Sarwar, G., Fahey, K. M., Gantt, B., Gilliam, R. C., Heath, N. K., Kang, D., Mathur, R., Schwede, D. B., Spero, T. L., Wong, D. C., and Young, J. O.: Description and evaluation of the Community Multiscale Air Quality (CMAQ) modeling system version 5.1, Geosci. Model Dev., 10, 1703-1732, https://doi.org/10.5194/gmd-10-1703-2017, 2017.

Bannan, T. J., Murray Booth, A., Bacak, A., Muller, J. B. A., Leather, K. E., Le Breton, M., Jones, B., Young, D., Coe, H., Allan, J., Visser, S., Slowik, J. G., Furger, M., Prévôt, A. S. H., Lee, J., Dunmore, R. E., Hopkins, J. R., Hamilton, J. F., Lewis, A. C., 
Whalley, L. K., Sharp, T., Stone, D., Heard, D. E., Fleming, Z. L., Leigh, R., Shallcross, D. E., and Percival, C. J.: The first UK measurements of nitryl chloride using a chemical ionization mass spectrometer in central London in the summer of 2012, and an investigation of the role of $\mathrm{Cl}$ atom oxidation, J. Geophys. Res., 120, 5638-5657, https://doi.org/10.1002/2014JD022629, 2015.

Bannan, T. J., Bacak, A., Le Breton, M., Flynn, M., Ouyang, B., McLeod, M., Jones, R., Malkin, T. L., Whalley, L. K., Heard, D. E., Bandy, B., Khan, M. A. H., Shallcross, D. E., and Percival, C. J.: Ground and airborne UK measurements of nitryl chloride: An investigation of the role of $\mathrm{Cl}$ atom oxidation at Weybourne Atmospheric Observatory, J. Geophys. Res.-Atmos., 122, 11154 11165, https://doi.org/10.1002/2017JD026624, 2017

Bitter, M., Ball, S. M., Povey, I. M., and Jones, R. L.: A broadband cavity ringdown spectrometer for in-situ measurements of atmospheric trace gases, Atmos. Chem. Phys., 5, 2547-2560, https://doi.org/10.5194/acp-5-2547-2005, 2005.

Borge, R., Alexandrov, V., José del Vas, J., Lumbreras, J., and Rodríguez, E.: A comprehensive sensitivity analysis of the WRF model for air quality applications over the Iberian Peninsula, Atmos. Environ., 42, 8560-8574, https://doi.org/10.1016/j.atmosenv.2008.08.032, 2008a.

Borge, R., Lumbreras, J., and Rodríguez, E.: Development of a high-resolution emission inventory for Spain using the SMOKE modelling system: A case study for the years 2000 and 2010, Environ. Model. Softw., 23, 1026-1044, https://doi.org/10.1016/j.envsoft.2007.11.002, 2008b.

Byun, D. and Schere, K. L.: Review of the Governing Equations, Computational Algorithms, and Other Components of the Models-3 Community Multiscale Air Quality (CMAQ) Modeling System, Appl. Mech. Rev., 59, 51-77, https://doi.org/10.1115/1.2128636, 2006.

Byun, D. W. and Ching, J. K. S.: Science Algorithms of the EPA MODELS-3 Community Multiscale Air Quality (CMAQ) Modelling System. U.S. Environmental Protection Agency, Washington, D.C., EPA/600/R-99/030 (NTIS PB2000-100561), 1999.

Commane, R., Seitz, K., Bale, C. S. E., Bloss, W. J., Buxmann, J., Ingham, T., Platt, U., Pöhler, D., and Heard, D. E.: Iodine monoxide at a clean marine coastal site: observations of high frequency variations and inhomogeneous distributions, Atmos. Chem. Phys., 11, 6721-6733, https://doi.org/10.5194/acp11-6721-2011, 2011.

de la Paz, D., Borge, R., and Martilli, A.: Assessment of a high resolution annual WRF-BEP/CMAQ simulation for the urban area of Madrid (Spain), Atmos. Environ., 144, 282-296, https://doi.org/10.1016/j.atmosenv.2016.08.082, 2016.

EEA (European Environmental Agency): Air Quality in Europe - 2018 report, EEA, Luxembourg, 12/2018, 83 pp., https://doi.org/10.2800/777411, 2018a.

EEA (European Environmental Agency): European Union emission inventory report 1990-2016 under the UNECE Convention on Long-range Transboundary Air Pollution (LRTAP), EEA, Luxembourg, 6/2018, 150 pp., https://doi.org/10.2800/571876, $2018 b$.

Eger, P. G., Friedrich, N., Schuladen, J., Shenolikar, J., Fischer, H., Tadic, I., Harder, H., Martinez, M., Rohloff, R., Tauer, S., Drewnick, F., Fachinger, F., Brooks, J., Darbyshire, E., Sciare, J., Pikridas, M., Lelieveld, J., and Crowley, J. N.: Shipborne measurements of $\mathrm{ClNO}_{2}$ in the Mediterranean Sea and around the Arabian Peninsula during summer, Atmos. Chem. Phys., 19, 12121-12140, https://doi.org/10.5194/acp-19-121212019, 2019.

EMEP/CEIP: Present state of emissions as used in EMEP models, available at: http://www.ceip.at/webdab_emepdatabase/ emissions_emepmodels (last access: 22 November 2019), 2014.

Farman, J. C., Gardiner, B. G., and Shanklin, J. D.: Large losses of total ozone in Antarctica reveal seasonal $\mathrm{ClO}_{x} / \mathrm{NO}_{x}$ interaction, Nature, 315, 207-210, https://doi.org/10.1038/315207a0, 1985.

Fernandez, R. P., Salawitch, R. J., Kinnison, D. E., Lamarque, J.-F., and Saiz-Lopez, A.: Bromine partitioning in the tropical tropopause layer: implications for stratospheric injection, Atmos. Chem. Phys., 14, 13391-13410, https://doi.org/10.5194/acp-1413391-2014, 2014.

Foley, K. M., Roselle, S. J., Appel, K. W., Bhave, P. V., Pleim, J. E., Otte, T. L., Mathur, R., Sarwar, G., Young, J. O., Gilliam, R. C., Nolte, C. G., Kelly, J. T., Gilliland, A. B., and Bash, J. O.: Incremental testing of the Community Multiscale Air Quality (CMAQ) modeling system version 4.7, Geosci. Model Dev., 3, 205-226, https://doi.org/10.5194/gmd-3-205-2010, 2010.

Furneaux, K. L., Whalley, L. K., Heard, D. E., Atkinson, H. M., Bloss, W. J., Flynn, M. J., Gallagher, M. W., Ingham, T., Kramer, L., Lee, J. D., Leigh, R., McFiggans, G. B., Mahajan, A. S., Monks, P. S., Oetjen, H., Plane, J. M. C., and Whitehead, J. D.: Measurements of iodine monoxide at a semi polluted coastal location, Atmos. Chem. Phys., 10, 3645-3663, https://doi.org/10.5194/acp-10-3645-2010, 2010.

Gantt, B., Sarwar, G., Xing, J., Simon, H., Schwede, D., Hutzell, W. T., Mathur, R., and Saiz-Lopez, A.: The Impact of Iodide-Mediated Ozone Deposition and Halogen Chemistry on Surface Ozone Concentrations Across the Continental United States, Environ. Sci. Technol., 51, 1458-1466, https://doi.org/10.1021/acs.est.6b03556, 2017.

Guenther, A. B., Jiang, X., Heald, C. L., Sakulyanontvittaya, T., Duhl, T., Emmons, L. K., and Wang, X.: The Model of Emissions of Gases and Aerosols from Nature version 2.1 (MEGAN2.1): an extended and updated framework for modeling biogenic emissions, Geosci. Model Dev., 5, 1471-1492, https://doi.org/10.5194/gmd-5-1471-2012, 2012.

Holla, R., Schmitt, S., Frieß, U., Pöhler, D., Zingler, J., Corsmeier, U., and Platt, U.: Vertical distribution of $\mathrm{BrO}$ in the boundary layer at the Dead Sea, Environ. Chem., 12, 438-460, https://doi.org/10.1071/EN14224, 2015.

Hossaini, R., Chipperfield, M. P., Saiz-Lopez, A., Harrison, J. J., Von Glasow, R., Sommariva, R., Atlas, E., Navarro, M., Montzka, S. A., Feng, W., Dhomse, S., Harth, C., Mühle, J., Lunder, C., O'Doherty, S., Young, D., Reimann, S., Vollmer, M. K., Krummel, P. B., and Bernath, P. F.: Growth in stratospheric chlorine from short-lived chemicals not controlled by the Montreal Protocol, Geophys. Res. Lett., 42, 4573-4580, https://doi.org/10.1002/2015GL063783, 2015.

Hossaini, R., Chipperfield, M. P., Saiz-Lopez, A., Fernandez, R., Monks, S., Feng, W., Brauer, P., and Von Glasow, R.: A global model of tropospheric chlorine chemistry: Organic versus inorganic sources and impact on methane oxidation, J. Geophys. Res., 121, 14271-14297, https://doi.org/10.1002/2016JD025756, 2016.

Jerrett, M., Burnett, R. T., Pope, C. A., Ito, K., Thurston, G., Krewski, D., Shi, Y., Calle, E., and Thun, M.: Long-Term Ozone 
Exposure and Mortality, New Engl. J. Med., 360, 1085-1095, https://doi.org/10.1056/NEJMoa0803894, 2009.

Jung, J., Lee, J., Kim, B., and Oh, S.: Seasonal variations in the $\mathrm{NO}_{2}$ artifact from chemiluminescence measurements with a molybdenum converter at a suburban site in Korea (downwind of the Asian continental outflow) during 2015-2016, Atmos. Environ., 165, 290-300, 2017.

Keene, W., Khalil, M. A. K., Erickson, D., McCulloch, A., Graedel, T. E., Lobert, J. M., Aucott, M. L., Gong, S. L., Harper, D. B., Kleiman, G., Midgley, P., Moore, R. M., Seuzaret, C., Sturges, W. T., Benkovitz, C. M., Koropalov, V., Barrie, L. A., and Li, Y. F.: Composite global emissions of reactive chlorine from anthropogenic and natural sources: Reactive Chlorine Emissions Inventory, J. Geophys. Res., 104, 8429-8440, 1999.

Kuklinska, K., Wolska, L., and Namiesnik, J.: Air quality policy in the U.S. and the EU - a review, Atmos. Pollut. Res., 6, 129-137, https://doi.org/10.5094/APR.2015.015, 2015.

Li, Q., Zhang, L., Wang, T., Tham, Y. J., Ahmadov, R., Xue, L., Zhang, Q., and Zheng, J.: Impacts of heterogeneous uptake of dinitrogen pentoxide and chlorine activation on ozone and reactive nitrogen partitioning: improvement and application of the WRF-Chem model in southern China, Atmos. Chem. Phys., 16, 14875-14890, https://doi.org/10.5194/acp-16-148752016, 2016.

Li, Q., Zhang, L., Wang, T., Wang, Z., Fu, X., and Zhang, Q.: "New" Reactive Nitrogen Chemistry Reshapes the Relationship of Ozone to Its Precursors, Environ. Sci. Technol., 52, 2810 2818, https://doi.org/10.1021/acs.est.7b05771, 2018.

Mahajan, A. S., Oetjen, H., Lee, J. D., Saiz-Lopez, A., McFiggans, G. B., and Plane, J. M. C.: High bromine oxide concentrations in the semi-polluted boundary layer, Atmos. Environ., 43, 38113818, https://doi.org/10.1016/j.atmosenv.2009.05.033, 2009.

Malley, C. S., Henze, D. K., Kuylenstierna, J. C. I., Vallack, H. W., Davila, Y., Anenberg, S. C., Turner, M. C., and Ashmore, M. R.: Updated Global Estimates of Respiratory Mortality in Adults $\geq 30$ Years of Age Attributable to LongTerm Ozone Exposure, Environ. Health Persp., 125, 87021, https://doi.org/10.1289/EHP1390, 2017.

Mathur, R., Xing, J., Gilliam, R., Sarwar, G., Hogrefe, C., Pleim, J., Pouliot, G., Roselle, S., Spero, T. L., Wong, D. C., and Young, J.: Extending the Community Multiscale Air Quality (CMAQ) modeling system to hemispheric scales: overview of process considerations and initial applications, Atmos. Chem. Phys., 17, 12449-12474, https://doi.org/10.5194/acp-17-124492017, 2017.

Matveev, V., Peleg, M., Rosen, D., Tov-Alper, D. S., Hebestreit, K., Stutz, J., Platt, U., Blake, D., and Luria, M.: Bromine oxideozone interaction over the Dead Sea, J. Geophys. Res., 106, 10375-10387, https://doi.org/10.1029/2000JD900611, 2001.

Mills, G., Pleijel, H., Braun, S., Büker, P., Bermejo, V., Calvo, E., Danielsson, H., Emberson, L., Fernández, I. G., Grünhage, L., Harmens, H., Hayes, F., Karlsson, P.-E., and Simpson, D.: New stomatal flux-based critical levels for ozone effects on vegetation, Atmos. Environ., 45, 5064-5068, https://doi.org/10.1016/j.atmosenv.2011.06.009, 2011.

Molina, M. J. and Rowland, F. S.: Stratospheric sink for chlorofluoromethanes: chlorine atom-catalysed destruction of ozone, Nature, 249, 810-812, https://doi.org/10.1038/249810a0, 1974.
Muñiz-Unamunzaga, M., Borge, R., Sarwar, G., Gantt, B., de la Paz, D., Cuevas, C. A., and Saiz-Lopez, A.: The influence of ocean halogen and sulfur emissions in the air quality of a coastal megacity: The case of Los Angeles, Sci. Total Environ., 610-611, 1536-1545, https://doi.org/10.1016/j.scitotenv.2017.06.098, 2018.

Osthoff, H. D., Roberts, J. M., Ravishankara, A. R., Williams, E. J., Lerner, B. M., Sommariva, R., Bates, T. S., Coffman, D., Quinn, P. K., Dibb, J. E., Stark, H., Burkholder, J. B., Talukdar, R. K., Meagher, J., Fehsenfeld, F. C., and Brown, S. S.: High levels of nitryl chloride in the polluted subtropical marine boundary layer, Nat. Geosci., 1, 324-328, https://doi.org/10.1038/ngeo177, 2008.

Peters, C., Pechtl, S., Stutz, J., Hebestreit, K., Hönninger, G., Heumann, K. G., Schwarz, A., Winterlik, J., and Platt, U.: Reactive and organic halogen species in three different European coastal environments, Atmos. Chem. Phys., 5, 3357-3375, https://doi.org/10.5194/acp-5-3357-2005, 2005.

Phillips, G. J., Tang, M. J., Thieser, J., Brickwedde, B., Schuster, G., Bohn, B., Lelieveld, J., and Crowley, J. N.: Significant concentrations of nitryl chloride observed in rural continental Europe associated with the influence of sea salt chloride and anthropogenic emissions, Geophys. Res. Lett., 39, L10811, https://doi.org/10.1029/2012GL051912, 2012.

Prados-Roman, C., Cuevas, C. A., Hay, T., Fernandez, R. P., Mahajan, A. S., Royer, S.-J., Galí, M., Simó, R., Dachs, J., Großmann, K., Kinnison, D. E., Lamarque, J.-F., and Saiz-Lopez, A.: Iodine oxide in the global marine boundary layer, Atmos. Chem. Phys., 15, 583-593, https://doi.org/10.5194/acp-15-583-2015, 2015.

Saiz-Lopez, A. and von Glasow, R.: Reactive halogen chemistry in the troposphere, Chem. Soc. Rev., 41, 6448-6472, https://doi.org/10.1039/c2cs35208g, 2012.

Saiz-Lopez, A., Plane, J. M. C., and Shillito, J. A.: Bromine oxide in the mid-latitude marine boundary layer, Geophys. Res. Lett., 31, L03111, https://doi.org/10.1029/2003GL018956, 2004.

Saiz-Lopez, A., Fernandez, R. P., Ordóñez, C., Kinnison, D. E., Gómez Martín, J. C., Lamarque, J.-F., and Tilmes, S.: Iodine chemistry in the troposphere and its effect on ozone, Atmos. Chem. Phys., 14, 13119-13143, https://doi.org/10.5194/acp-1413119-2014, 2014.

Sarwar, G., Simon, H., Bhave, P., and Yarwood, G.: Examining the impact of heterogeneous nitryl chloride production on air quality across the United States, Atmos. Chem. Phys., 12, 6455-6473, https://doi.org/10.5194/acp-12-6455-2012, 2012.

Sarwar, G., Simon, H., Xing, J., and Mathur, R.: Importance of tropospheric $\mathrm{ClNO}_{2}$ chemistry across the Northern Hemisphere, Geophys. Res. Lett., 41, 4050-4058, https://doi.org/10.1002/2014GL059962, 2014.

Sarwar, G., Gantt, B., Schwede, D., Foley, K., Mathur, R., and Saiz-Lopez, A.: Impact of Enhanced Ozone Deposition and Halogen Chemistry on Tropospheric Ozone over the Northern Hemisphere, Environ. Sci. Technol., 49, 9203-9211, https://doi.org/10.1021/acs.est.5b01657, 2015.

Sarwar, G., Gantt, B., Foley, K., Fahey, K., Spero T. L., Kang, D., Mathur, R., Hosein F., Xing, J., Sherwen, T., and Saiz-Lopez, A.: Influence of bromine and iodine chemistry on annual, seasonal, diurnal, and background ozone: CMAQ simulations over the Northern Hemisphere, Atmos. Environ., 213, 395-404, 2019. 
Sherwen, T., Schmidt, J. A., Evans, M. J., Carpenter, L. J., Großmann, K., Eastham, S. D., Jacob, D. J., Dix, B., Koenig, T. K., Sinreich, R., Ortega, I., Volkamer, R., Saiz-Lopez, A., PradosRoman, C., Mahajan, A. S., and Ordóñez, C.: Global impacts of tropospheric halogens $(\mathrm{Cl}, \mathrm{Br}, \mathrm{I})$ on oxidants and composition in GEOS-Chem, Atmos. Chem. Phys., 16, 12239-12271, https://doi.org/10.5194/acp-16-12239-2016, 2016.

Sherwen, T., Evans, M. J., Sommariva, R., Hollis, L. D. J., Ball, S. M., Monks, P. S., Reed, C., Carpenter, L. J., Lee, J. D., Forster, G., Bandy, B., Reeves, C. E., and Bloss, W. J.: Effects of halogens on European air-quality, Faraday Discuss., 200, 75-100, https://doi.org/10.1039/c7fd00026j, 2017.

Sillman, S.: The relation between ozone, $\mathrm{NO}_{x}$ and hydrocarbons in urban and polluted rural environments, Atmos. Environ., 33, 1821-1845, https://doi.org/10.1016/S1352-2310(98)003458, 1999.

Simpson, W. R., Brown, S. S., Saiz-Lopez, A., Thornton, J. A., and Von Glasow, R.: Tropospheric Halogen Chemistry: Sources, Cycling, and Impacts, Chem. Rev., 115, 4035-4062, https://doi.org/10.1021/cr5006638, 2015.

Skamarock, W. C. and Klemp, J. B.: A time-split nonhydrostatic atmospheric model for weather research and forecasting applications, J. Comput. Phys., 227, 3465-3485, https://doi.org/10.1016/j.jcp.2007.01.037, 2008.

Solazzo, E., Hogrefe, C., Colette, A., Garcia-Vivanco, M., and Galmarini, S.: Advanced error diagnostics of the CMAQ and Chimere modelling systems within the AQMEII3 model evaluation framework, Atmos. Chem. Phys., 17, 10435-10465, https://doi.org/10.5194/acp-17-10435-2017, 2017.

Sommariva, R., Hollis, L. D. J., Sherwen, T., Baker, A. R., Ball, S. M., Bandy, B. J., Bell, T. G., Chowdhury, M. N., Cordell, R. L., Evans, M. J., Lee, J. D., Reed, C., Reeves, C. E., Roberts, J. M., Yang, M., and Monks, P. S.: Seasonal and geographical variability of nitryl chloride and its precursors in Northern Europe, Atmos. Sci. Lett., 19, e844, https://doi.org/10.1002/asl.844, 2018.

Stone, D., Sherwen, T., Evans, M. J., Vaughan, S., Ingham, T., Whalley, L. K., Edwards, P. M., Read, K. A., Lee, J. D., Moller, S. J., Carpenter, L. J., Lewis, A. C., and Heard, D. E.: Impacts of bromine and iodine chemistry on tropospheric $\mathrm{OH}$ and $\mathrm{HO}_{2}$ : comparing observations with box and global model perspectives, Atmos. Chem. Phys., 18, 3541-3561, https://doi.org/10.5194/acp-18-3541-2018, 2018.

Tas, E., Peleg, M., Pedersen, D. U., Matveev, V., Pour Biazar, A., and Luria, M.: Measurement-based modeling of bromine chemistry in the boundary layer: 1 . Bromine chemistry at the Dead Sea, Atmos. Chem. Phys., 6, 5589-5604, https://doi.org/10.5194/acp-6-5589-2006, 2006.
Tham, Y. J., Wang, Z., Li, Q., Yun, H., Wang, W., Wang, X., Xue, L., Lu, K., Ma, N., Bohn, B., Li, X., Kecorius, S., Größ, J., Shao, M., Wiedensohler, A., Zhang, Y., and Wang, T.: Significant concentrations of nitryl chloride sustained in the morning: investigations of the causes and impacts on ozone production in a polluted region of northern China, Atmos. Chem. Phys., 16, 14959-14977, https://doi.org/10.5194/acp-16-14959-2016, 2016.

Thornton, J. A., Kercher, J. P., Riedel, T. P., Wagner, N. L., Cozic, J., Holloway, J. S., Dubé, W. P., Wolfe, G. M., Quinn, P. K., Middlebrook, A. M., Alexander, B., and Brown, S. S.: A large atomic chlorine source inferred from midcontinental reactive nitrogen chemistry, Nature, 464, 271-274, https://doi.org/10.1038/nature08905, 2010.

UNC (University of North Carolina at Chapel Hill): SMOKE v3.6.5 User's Manual, Institute for the Environment, available at: https: //www.cmascenter.org/smoke/documentation/3.6.5/html (last access: 22 November 2019), 2015.

US EPA Office of Research and Development (ORD): CMAQ (Version 5.2), Zenodo, https://doi.org/10.5281/zenodo.1167892, 30 June 2017.

van Loon, M., Vautard, R., Schaap, M., Bergström, R., Bessagnet, B., Brandt, J., Builtjes, P. J. H., Christensen, J. H., Cuvelier, C., Graff, A., Jonson, J. E., Krol, M., Langner, J., Roberts, P., Rouil, L., Stern, R., Tarrasón, L., Thunis, P., Vignati, E., White, L., and Wind, P.: Evaluation of long-term ozone simulations from seven regional air quality models and their ensemble, Atmos. Environ., 41, 2083-2097, https://doi.org/10.1016/j.atmosenv.2006.10.073, 2007.

Wang, T., Tham, Y. J., Xue, L., Li, Q., Zha, Q., Wang, Z., Poon, S. C. N., Dubé, W. P., Blake, D. R., Louie, P. K. K., Luk, C W. Y., Tsui, W., and Brown, S. S.: Observations of nitryl chloride and modeling its source and effect on ozone in the planetary boundary layer of southern China, J. Geophys. Res.-Atmos., 121, 2476-2489, https://doi.org/10.1002/2015JD024556, 2016.

Wang, X., Jacob, D. J., Eastham, S. D., Sulprizio, M. P., Zhu, L., Chen, Q., Alexander, B., Sherwen, T., Evans, M. J., Lee, B. H., Haskins, J. D., Lopez-Hilfiker, F. D., Thornton, J. A., Huey, G. L., and Liao, H.: The role of chlorine in global tropospheric chemistry, Atmos. Chem. Phys., 19, 3981-4003, https://doi.org/10.5194/acp-19-3981-2019, 2019. 